Z Badań nad Książką i Księgozbiorami Historycznymi 2020, t. 14, z. 1

Agnieszka Łuszpak

Instytut Informacji Naukowej i Bibliotekoznawstwa

Uniwersytet Wrocławski

agnieszka.luszpak@uwr.edu.pl

(iD) 0000-0002-2926-5745

\title{
Walka o czytelnika - koncepcje pracy bibliotecznej w świetle publikacji zamieszczanych na łamach polskich czasopism bibliotekarskich w okresie stalinowskim
}

\section{Fight for the reader - concepts of library work in the light of materials published in Polish librarianship magazines in the Stalinist period}

\begin{abstract}
In the Stalinist period (1948-1956) new challenges appeared in the work of Polish librarians. One of them was work competition, considered an ideal way of supporting the building of socialism. The next one service for new groups of readers, i.e. peasants and workers, who had to be provided with an ideological book to understand and accept the new system, and professional, to contribute to the economic development of the country. These tasks required rigorous control of lending and selection of book collections. In the journals, published by the Związek Bibliotekarzy i Archiwistów Polskich - "Przegląd Biblioteczny”, "Bibliotekarz" and "Poradnik Bibliotekarza" - you can find various materials to help librarians carry out new tasks.
\end{abstract}

Key words: librarianship - work competition - peasants reading - workers reading - childrens reading - book selection - Stalinist period - Poland.

Słowa kluczowe: bibliotekarstwo - współzawodnictwo pracy - czytelnictwo chłopów czytelnictwo robotników - czytelnictwo dzieci - selekcja księgozbiorów - okres stalinowski Polska.

„Z Badań nad Książką i Księgozbiorami Historycznymi” - Udział zagranicznych recenzentów w ocenie publikacji; Stworzenie anglojęzycznej wersji wydawniczej publikacji; Digitalizacja tomów archiwalnych rocznika w celu zapewnienia otwartego dostępu do nich przez Internet oraz wdrożenie i utrzymanie cyfrowej platformy redakcyjnej - zadanie finansowane w ramach umowy nr 653/P-DUN/2019 ze środków Ministra Nauki i Szkolnictwa Wyższego przeznaczonych na działalność upowszechniającą naukę. 


\section{Wstęp}

W 1947 r. przeniesiono z ZSRR do Polski hasło współzawodnictwa pracy - i właściwie natychmiast ideę tę zaczęły głosić czasopisma bibliotekarskie. Ostateczny już powojenny zwrot polityczny z 1948 r. (zdobycie pełni władzy przez komunistów, utworzenie PZPR i podporządkowanie partii życia społecznego i gospodarczego, objęcie przywództwa przez B. Bieruta, plan kolektywizacji rolnictwa, ideologizacja życia kulturalnego i naukowego) gloryfikował „ludzi pracy”, zwłaszcza przodowników, w konstytucji z 1952 r. zaznaczono dominującą rolę „ludu pracującego miast i wsi”, prasa fachowa skupiła się więc na czytelnictwie tych grup społecznych. W Planie Sześcioletnim założono intensywną industrializację kraju, a także zintensyfikowanie procesów kolektywizacji rolnictwa - i w czasopismach dla bibliotekarzy podkreślano, że to właśnie dzięki lekturze można podnieść wydajność produkcji przemysłowej i rolnej oraz przekonać chłopów do idei pracy spółdzielczej'

Według ówczesnych decydentów prasa może odgrywać istotną rolę w kształtowaniu nowego, socjalistycznego człowieka. Przekonują o tym choćby wypowiedzi partyjnych dygnitarzy z tamtego okresu. Jeszcze w 1956 r., u schyłku stalinizmu, wicepremier Piotr Jaroszewicz podczas VIII Plenum KC PZPR pozytywnie wypowiadał się o roli prasy i „całego frontu kulturalnego", gdyż „urabia ona i rozładowuje nastroje społeczne”, ponadto

Prasę czyta społeczeństwo, prasa cieszy się zaufaniem szerokich mas, prasa ma sojuszników w partii i społeczeństwie. Trzeba zbliżyć się do prasy, trzeba nią pokierować, trzeba wykorzystywać prasę do umacniania więzi partii z masami³.

Redakcje czasopism wydawanych przez ZBiAP (od 1953 r. noszącego nazwę SBP) zarówno tych o przedwojennym rodowodzie, jak „Przegląd Biblioteczny” i „Bibliotekarz”, jak i powojennego „Poradnika Bibliotekarza” umacniały te więzi, angażując się w propagowanie nowych idei na swych łamach poprzez ukazywanie, w jaki sposób bibliotekarze mogą przyczynić się do zrealizowania wizji lepszego świata. Nie tylko akcentowały polityczną rolę bibliotekarza (jednym z ważniejszych zagadnień na łamach ówczesnych czasopism było nastawienie ideologiczne pracowników bibliotek ${ }^{4}$ ), lecz także

\footnotetext{
Literatura naukowa dotycząca spraw książki w okresie stalinizmu jest dość bogata, nie sposób przywołać tu wszystkich tytułów (kilka z nich znalazło się w bibliografii). Na pewno warto zajrzeć do prac Agnieszki Chamery-Nowak, Dariusza Jarosza, Kamili Kamińskiej-Chełminiak, Stanisława Kondka, Jacka Puchalskiego Zbigniewa Romka czy Marka Tobery. Wspomniani autorzy analizowali problemy upolitycznienia kwestii związanych z książką na podstawie różnych materiałów. W tym artykule skupiłam się jedynie na pokazaniu obrazu tego zjawiska wyłaniającego się z analizy materiałów zamieszczonych w prasie bibliotekarskiej.

Wypowiedź Piotra Jaroszewicza na VIII Plenum KC PZPR, „Nowe Drogi” 1956, t. 10, nr 10, s. 57.

Tamże, s. 58.

4 A. Łuszpak, ,Nie poszliśmy więc do polityki. Ale oto polityka przyszła do nas” - rola biblio-
} 
nakazywały mu skupienie się na pewnych zadaniach, uznanych w pracy bibliotekarskiej za ważniejsze od innych ${ }^{5}$.

\section{Współzawodnictwo i normy pracy}

Dość powszechne zjawisko, jakim w krajach bloku sowieckiego pod koniec lat 40. XX w. było - zwykle wprowadzane odgórnie - współzawodnictwo, nie ominęło „odcinka” pracy bibliotecznej. Zdawać by się mogło, że trudno prowadzić rywalizację w dziedzinie tak ulotnej, jak przekazywanie myśli ludzkich zawartych w książkach czy prasie, że trudno znaleźć pola, na jakich takie współzawodnictwo mogłoby się rozegrać, jednak inicjatywy tego typu przedstawiano na łamach bibliotekarskiej prasy fachowej już w 1948 r. W grudniu w „Bibliotekarzu” zamieszczono informację, że pracownicy BUW oraz pracownicy bibliotek samorządowych powiatu krotoszyńskiego postanowili wziąć udział we współzawodnictwie pracy (ci ostatni zobowiązali się wykonać przedterminowo plan roczny na 1948 r.). Redakcja podkreślała z aprobatą:

Oto dwie informacje, wyłowione na chybił trafił z powodzi wiadomości o wkładach wzmożonego wysiłku, jakimi polski świat pracy witał kongres Zjednoczeniowy Partii Robotniczych. Przytoczono je tu jako wymowną ilustrację faktu, że szeregi bibliotekarzy nie grzęzną już w fikcji «apolityczności», «neutralnej oświaty», tak wytrwale przez długie lata kultywowanej6.

Na początku kwietnia 1949 r. podczas zebrania Delegatów Kół ZBiAP we Wrocławiu ustalono, że koniecznie należy zorganizować współzawodnictwo w bibliotekach na większą skalę. Postanowiono jak najszybciej opracować odpowiednie druki oraz wypracować normy pracy, gdyż ich brak utrudniał to zadanie ${ }^{7}$. A pojawiały się już pytania, dlaczego wśród przodowników pracy brak nazwisk bibliotekarzy? Dlaczego nie włączają się oni w budowę socjalizmu? Zarząd Związku wziął winę na siebie tłumacząc, że ,Zagadnienie racjonalizacji i współzawodnictwa dopiero teraz są rozpatrywane zasadniczo

tekarza w okresie stalinowskim (w świetle materiałów zamieszczanych na łamach polskich czasopism zawodowych), „Z Badań nad Książką i Księgozbiorami Historycznymi” 2018, tom 12, s. 273-305.

5 Analizą objęto wszystkie materiały prasowe opublikowane w wymienionych czasopismach w latach 1948-1956 (w „Poradniku” od 1949 r., gdyż wtedy zaczął się ukazywać). Nie dokonywano między nimi rozróżnień, zgodnie z podejściem Janiny Pelcowej, która we Wstępie do Bibliografii zawartości „Przeglądu Bibliotecznego” $1927-1976$ (r. 1-44), Wrocław 1978, pisała, iż oprócz artykułów, doniesień, sprawozdań oraz recenzji książek i czasopism równie istotne wydają się ,krótkie informacje wchodzące w skład kronik krajowych i zagranicznych. Te ostatnie uwzględniono, gdyż sygnalizują różne aktualne wydarzenia, znajdujące niekiedy (oczywiście znacznie później) swe odbicie w odpowiednich artykułach czy sprawozdaniach; zdarza się, że notatki te są jedynym źródłem informacji o interesujących nas faktach" (s. 11).

6 Na nowej karcie, „Bibliotekarz” 1948, nr 12, s. 177.

7 Kronika: Protokól Zebrania Delegatów Kół ZBiAP obradującego w dniach 8-9 kwietnia w lokalu Biblioteki Ossolineum we Wrocławiu, „Przegląd Biblioteczny” 1949, t. 17, z. 1-2, s. 131, 132. 
i praktycznie w naszym gronie"». Uznano, że koła organizacji powinny zgłaszać wyróżniających się pracowników bibliotek, ale nastąpiło to po raz pierwszy dopiero w 1949 r. W tym samym roku Komisja Normalizacyjna przedstawiła projekt $\mathrm{w}$ zakresie ustalenia podstaw współzawodnictwa pracy ${ }^{9}$, a i tak rok później na łamach „Bibliotekarza” narzekano, że do współzawodnictwa bibliotekarze polscy przystąpili z opóźnieniem ${ }^{10}$. Także w 1950 r. w czasie Walnego Zjazdu Delegatów Kół ZBiAP podjęto rezolucję, w której wezwano „wszystkich bibliotekarzy i archiwistów do podjęcia współzawodnictwa na wszystkich odcinkach pracy bibliotecznej i archiwalnej w służbie kultury i postępowej myśli naukowej" "11. Podkreślono, że szkolenie bibliotekarzy na obecnym etapie powinno wykorzystywać wzory radzieckie, jako najbardziej postępowe, zwłaszcza że towarzysze z ZSRR chętnie uczestniczą we współzawodnictwie. W tym samym czasie w „Bibliotekarzu” pojawił się osobny dział: „Z frontu współzawodnictwa pracy". Widocznie uznano, że tych doniesień będzie na tyle dużo i że są na tyle ważne, by wyróżnić je i oddzielić od innych treści. Pisano: „Współzawodnictwo pracy jest podstawową metodą budowania socjalizmu”; ma ono mobilizować do „doskonalenia działalności bibliotek, jak najściślejszego wiązania jej z potrzebami chwili, z realizacją zadań politycznych, gospodarczych i kulturalnych"'12. Brak odpowiednich norm pracy nie mógł więc być dłużej wymówką. Ponadto w czasie plenarnego posiedzenia Zarządu Głównego ZBiAP w styczniu 1950 r. „Kol. Horodyski [Bogdan Horodyski] podkreśla, że co innego są normy, co innego współzawodnictwo pracy. Współzawodnictwo należy wprowadzić jak najszybciej, niezależnie od opracowywania norm"13.

Bibliotekarzom, zakłopotanym nieco nowymi zadaniami, z pomocą przyszedł oczywiście Związek, podając konkretne przykłady uprawiania współzawodnictwa. Aby ułatwić przyswojenie nowych idei, w prasie bibliotekarskiej zamieszczono instrukcję wydaną przez ZG Związku Zawodowego Pracowników Państwowych, jak prowadzić współzawodnictwo ${ }^{14}$. Pojawiły się karty do wypełniania zadań, a także rankingi lepszych i gorszych we współzawodnictwie placówek ${ }^{15}$. Także w Sprawozdaniu sekretarza generalnego ZBiAP

8 O przodowników pracy w bibliotekarstwie, „Bibliotekarz” 1949, nr 9-10, s. 171.

9 Z życia Związku. Wyciag z protokólu zebrania Zarządu Głównego Związku w dniach 8 i 9 października 1949 r., „Bibliotekarz” 1949, nr 9-10, s. 162-164.

10 Wytyczne w sprawie wspólzawodnictwa pracy w bibliotekach, „Bibliotekarz” 1951, nr 3-4, s. 42 .

Z życia Związku. Walny Zjazd Delegatów Kót Z.B. i A.P., „Bibliotekarz” 1950, nr 3-4, s. 59.

Wytyczne w sprawie wspótzawodnictwa..., s. 42-43.

3 Sprawy ZBiAP. Protokót plenarnego posiedzenia Zarzadu Gtównego Zwiąku Bibliotekarzy i Archiwistów Polskich odbytego w dniach 28 i 29 stycznia 1950 r. w Państwowym Ośrodku Ksztatcenia Bibliotekarzy w Jarocinie, „Przegląd Biblioteczny” 1950, t. 18, z. 2, s. 183.

14 Redakcja, Z frontu wspótzawodnictwa pracy, „Bibliotekarz” 1951, nr 5-6, s. 83-85.

15 Z frontu wspólzawodnictwa pracy, „Bibliotekarz” 1950, nr 5-6, s. 74-80. 
za czas 7.IV-1.X.1949 r. ${ }^{16}$ czytamy o współzawodnictwie w poszczególnych kołach w zakresie: liczby książek, liczby czytelników, prowadzenia katalogów, zespołów głośnego czytania, samokształcenia, estetycznej oprawy książek itd. Działania te miały na celu „szersze upowszechnienie książki, zwiększenie liczby czytelników i rozbudzenie większego zainteresowania literaturą popularno-naukową"17.

Dlaczego współzawodnictwo było takie ważne? Gdyż miało umożliwić przestawienie się z pracy technicznej na pracę społeczną, mającą na celu przebudowę człowieka ${ }^{18}$. Sam Włodzimierz Lenin pisał, że „Bibliotekarstwo bardziej niż wszystko inne wymaga wywołania współzawodnictwa"19, więc nic dziwnego, że temat współzawodnictwa zaczął być intensywnie eksploatowany na łamach czasopism bibliotekarskich. W 1952 r. hasło to powtórzono w „Bibliotekarzu", podając Wytyczne organizacji wspótzawodnictwa w bibliotekach powszechnych przygotowane przez Ministerstwo Kultury i Sztuki ${ }^{20}$. Także w „Poradniku Bibliotekarza” podkreślano, że „Współzawodnictwo pracy stało się hasłem dnia. Współzawodniczą ze sobą fabryki i zakłady pracy, miasta i wsie, organizacje i związki, nawet dzieci w szkołach. Dlaczego biblioteki miałyby pozostać w tyle?"21, pytała retorycznie Wanda Dąbrowska z Olsztyna, dodając:

doskonale zdajemy sobie sprawę tego, że w socjalistycznym współzawodnictwie pracy odniesienie zwycięstwa nie jest momentem najważniejszym. Ważnym jest przede wszystkim to, iż całoroczny wzmożony nasz wysiłek, nasz codzienny trud i praca przyczynią się do szybszego rozwoju bibliotek i czytelnictwa ${ }^{22}$.

Redakcja namawiała biblioteki do dzielenia się doświadczeniami, co miałoby zachęcić inne placówki do przystąpienia do współzawodnictwa.

Niewątpliwie współzawodnictwo pracy w bibliotekarstwie było coraz bardziej widoczne. Pod koniec 1950 r. na naradzie bibliotekarzy pomorskich informowano, że to w tym właśnie roku pojawiły się w bibliotekarstwie dwa nowe pojęcia - współzawodnictwo biblioteczne oraz wytwórcze narady

16 J. Kraczkiewicz, Sprawozdanie sekretarza generalnego ZBiAP za czas 7.IV-1.X.1949 r., „Przegląd Biblioteczny” 1950, t. 18, z. 1, s. 60-76. Także J. Kraczkiewicz, Pod znakiem wielkich zadań, „Bibliotekarz” 1949, nr 9-10, s. 141-143 - jedno z zadań Związku to „pogłębianie współzawodnictwa pracy".

17 J.K., Biblioteka Publiczna m. Krakowa w roku 1950, „Bibliotekarz” 1951, nr 1-2, s. 30-31.

18 Kronika: Protokół Zebrania..., s. 132.

19 A. Zwoliński, Współzawodnictwo pracy bibliotek $w$ woj. warszawskim, „Bibliotekarz” 1951, nr 8-9, s. 137.

20 Wytyczne organizacji wspólzawodnictwa w bibliotekach powszechnych, „Bibliotekarz” 1952, nr 2, s. 48.

21 W. Dąbrowska, Wspólzawodnictwo w bibliotekach, „Poradnik Bibliotekarza” 1950, nr 3, s. 12 .

22 Tamże, s. 13. 
biblioteczne ${ }^{23}$, choć, jak widać z poprzednich akapitów, na łamach czasopism była o tym mowa już wcześniej. Pojęcia te niewątpliwie dobrze obrazowały nowy styl pracy. Tematy wystąpień podczas tych dwu dni spotkań to na przykład: Rola i zadania bibliotek w Planie 6-letnim; Wspótzawodnictwo biblioteczne jako podstawowa metoda zwiększenia wydajności pracy bibliotek; $Z$ doświadczeń współzawodnictwa bibliotek $w$ powiecie białogardzkim itp. Jasno widać, że coraz większe znaczenie w pracy bibliotekarza odgrywała ideologia, nie treści merytoryczne. W konkluzji tego spotkania znalazło się zresztą zdanie: „Dyskusja wykazała również konieczność wyjścia bibliotekarza poza warsztat bibliotekarski na teren zakładów pracy, do zebrań gromadzkich oraz niemniej pilną konieczność uspołecznienia i upolitycznienia bibliotecznego warsztatu pracy [sic! A.Ł.]”24, a ponadto „oparcie metod pracy badawczej na zasadach marksizmu-leninizmu” oraz „odrzucenie idealistycznego balastu nauki burżuazyjnej"25. Jeden z czołowych ideologów nowego bibliotekarstwa, Czesław Kozioł, pisał, iż

najważniejsze wyniki pracy bibliotekarza to wyniki jego działalności wychowawczo-politycznej, budzenie świadomości klasowej, mobilizowanie mas do walki o pokój, o realizację Planu 6-letniego, pobudzanie czytelników do samokształcenia, umiejętne kierowanie czytelnictwem" ${ }^{\prime 26}$,

a takie kwestie trudno ująć ilościowo i porównywać, ale bibliotekarze polscy mimo to próbowali rywalizować. Głównie w zakresie czytelnictwa - zarówno liczby czytelników, jak i wypożyczeń literatury marksistowskiej i popularno-naukowej. Także Zbigniew Kempka, inny aktywista nowego ładu, ubolewał na łamach „Bibliotekarza”, że współzawodnictwo i racjonalizatorstwo, te nowoczesne metody ,walki z zacofaniem ekonomicznym i wspomagania rozwoju sił wytwórczych", bardzo, niestety, kuleją w oświacie i nauce! A przecież biblioteki także powinny „współpracować w wychowaniu nowego człowieka, budowniczego państwa socjalistycznego" ${ }^{27}$. Na przykład BP m.st. Warszawy dopiero w 1950 r. wezwała do współzawodnictwa w propagowaniu odpowiedniej literatury i prasy biblioteki miejskie w Łodzi, Gdańsku, Poznaniu, Lublinie i Krakowie.

Przez kilka kolejnych lat pojawiały się kolejne doniesienia o czynach społecznych, wyzwaniach w zakresie udostępniania zbiorów, ich porządkowania czy zdobywania nowych czytelników. Jak wyglądały poszczególne inicjatywy?

23 S. Telega, Wielka narada wytwórcza bibliotekarzy Pomorza Zachodniego, „Bibliotekarz” 1950, nr 11-12, s. 178-180.

24 Tamże, s. 180.

25 Tamże.

26 C. Kozioł, Wspótzawodnictwo pracy w bibliotekach, „Poradnik Bibliotekarza” 1951, nr 2, s. 18.

27 Z. Kempka, Rola bibliotek w planie 6-letnim, „Bibliotekarz” 1950, nr 3-4, s. 33-40. 
Bibliotekarze warszawscy w 1950 r. w odpowiedzi na apel górnika Wiktora Markiefki uznali, że „obok robotnika budującego fundamenty Polaki Ludowej musi stanąć i bibliotekarz"28. W związku z tym zobowiązali się otwierać biblioteki godzinę wcześniej, opracować bibliografię dotyczącą spraw kobiecych w ustawodawstwie krajów demokracji ludowej, a bibliotekarze z Poznania podjęli współzawodnictwo w udostępnianiu literatury marksistowskiej i popularno-naukowej. Akcja współzawodnictwa wyraźnie nabierała rozmachu, podejmowano kolejne wyzwania, często z okazji rocznic obchodzonych w nowej rzeczywistości społeczno-politycznej: na przykład już w 1949 r. Zarząd Główny ZBiAP przypomniał poszczególnym kołom o konieczności uczczenia 70. rocznicy urodzin Józefa Stalina ${ }^{29}$. Zapowiedziano, że w styczniu kolejnego roku na plenarnym posiedzeniu przedstawione zostaną sprawozdania $\mathrm{z}$ tego wydarzenia. Niektóre koła już wcześniej podjęły działania w celu uczczenia urodzin „Generalissimusa”, na przykład w Bibliotece Uniwersyteckiej w Toruniu postanowiono przepracować bezpłatnie (zarówno pracownicy umysłowi, jak i fizyczni) trzy dni po trzy godziny, czyli w sumie 567 godzin roboczych. Na co poświęcono ten czas? Na segregowanie i porządkowanie księgozbioru poniemieckiego. Bibliotekarze uznali, że w ten sposób przyczynią się do wykonania Planu Sześcioletniego, czyli budowy socjalizmu w kraju. Inicjatywy tego typu podjęły też inne biblioteki. W „Przeglądzie” w 1949 r. przedstawiono szczegółowo czyny upamiętniające urodziny Stalina, podjęte w różnych placówkach ${ }^{30}$. Oprócz wspomnianej już Biblioteki Uniwersyteckiej w Toruniu czyn rocznicowy podjęły (raczej nie mając wyjścia, gdyż sugestie ZBiAP były dość jednoznaczne), następujące książnice: BN w Warszawie opracowała materiały dotyczące historii ruchu robotniczego w Polsce oraz postanowiła pogłębić w ciągu roku pracę nad poznaniem zasad marksizmu-leninizmu oraz historii i osiągnięć ZSRR, wysłano także adres do Stalina; podobnie postąpiła BUMCS, ponadto przeznaczyła cztery godziny pracy na porządkowanie lokalu bibliotecznego. Biblioteka Jagiellońska zobowiązała się do dodatkowych sześciu godzin pracy, BUP do dziewięciu, a Biblioteka KC PZPR dziesięciu; BUŁ stworzyła katalog ruchów społecznych, wzywając przy okazji inne książnice, by też takowy przygotowały; BSGPiS zorganizowała wystawę dzieł Stalina, przygotowała schemat wzorcowy do katalogu systematycznego działu Historia ZSRR, opracowała radzieckie wydawnictwa ciągłe zgodnie z przepisami używanymi w ZSRR, a w dziale druków zwartych zobowiązała się wykonać miesięczną pracę do 21 grudnia. W Bibliotece Szkoły Głównej Gospodarstwa Wiejskiego także zorganizowano wystawę dzieł Stalina, oprócz

28 Z frontu wspótzawodnictwa pracy, „Bibliotekarz” 1950, nr 3-4, s. 42.

29 Uczczenie 70-tej rocznicy urodzin Józefa Stalina, „Bibliotekarz” 1949, nr 11-12, s. 202-203.

$30 \quad$ Kronika. Udział bibliotekarzy i archiwistów polskich w uczczeniu 70 rocznicy urodzin Józefa Stalina, „Przegląd Biblioteczny” 1949, t. 17, z. 3-4, s. 223-226. 
tego zobowiązano się uporządkować ok. 1000 tomów do 1 stycznia. Dość enigmatycznie brzmiące zobowiązanie zadeklarowała BGUS - utrzymanie najwyższej dyscypliny pracy. Ponadto zgłosiła dziesięć godzin pracy dodatkowej i wzmożenie wysiłków nad usprawnieniem i wydajnością pracy. W Bibliotece Miejskiej w Poznaniu zorganizowano doraźną składkę, za pieniądze z której zakupiono 30 kompletów po pięć książek dla przodowników pracy PGR i po pięć kompletów dla przodowników pracy Wielkopolskich Zakładów Przemysłu Drzewnego. Książnica Miejska w Toruniu poświęciła dodatkowe 440 godzin na konserwację i organizację księgozbioru. W BP m.st. Warszawy 200 osób zadeklarowało dodatkową godzinę pracy, podczas której ustawiono księgozbiór (8300 tomów), poza tym przygotowano odpowiednie wystawki we wszystkich filiach biblioteki.

Także Koła ZBiAP włączyły się do czynu rocznicowego - organizowano zbiórki książek, zabawek, ubrań dla niewidomych dzieci; pokazy książek o ruchu robotniczym; szybciej opracowywano księgozbiór; uzupełniano zbiory o wydawnictwa radzieckie; studiowano życiorys Stalina; pracowano dodatkowo w niedziele; przygotowywano uroczyste akademie; dyżurowano podczas wystaw dzieł Stalina. To był tylko wybór najciekawszych inicjatyw, gdyż oczywiście wszystkie biblioteki wzięły udział - w ten czy inny sposób w obchodach rocznicy urodzin Stalina.

Kolejne inicjatywy przedstawiane w dziale „Z frontu współzawodnictwa pracy", tym razem ze Szczecina, Gdańska i Warszawy, to zwiększenie liczby czytelników o $10 \%$, intensywniejsze działania mające na celu propagandę czytelnictwa, konkursy dla czytelników, w których królowały pytania typu: jakie trzy powieści polskie wydane po 1945 r. uważam za najlepsze? jakie radzieckie? lub: na czym polega i co nam daje współzawodnictwo pracy, albo: dlaczego spółdzielczość produkcyjna jest wyższą formą gospodarki ${ }^{31}$. W Sprawozdaniu sekretarza generalnego Zarządu Gtównego ZBiAP za okres 9.IV.194914.IV.1950 $r^{32}$ czytamy, że pracownicy BP m.st. Warszawy postanowili podjąć współzawodnictwo długofalowe, gdyż uznali, że w budowie socjalizmu nie chodzi o akcje jednorazowe, lecz o stały wysiłek. Znajduje się tam także informacja, że „Zalecono, aby na czyn 1 Maja zostały podejmowane zobowiązania, zgłaszane współzawodnictwo w pracach nad organizacją nowych bibliotek, pozyskiwaniem nowych czytelników, uaktywnianiem czytelników itp." ${ }^{33}$.

Rok 1952 także był dobrym czasem dla współzawodnictwa - podejmowano zobowiązania z okazji 60. urodzin Bolesława Bieruta i w związku z obchodami

31 Por. Z frontu wspótzawodnictwa pracy, „Bibliotekarz” 1950, nr 5-6, s. 74-80; Z frontu wspótzawodnictwa pracy, „Bibliotekarz” 1950, nr 7-8, s. 118-119.

32 Sprawozdanie sekretarza generalnego Zarzadu Glównego ZBiAP za okres 9.IV.1949-14. IV.1950 r., „Przegląd Biblioteczny” 1950, t. 18, z. 3-4, s. 313.

33 Tamże, s. 314. 
dnia 1 Maja (daty te dzieliło zaledwie kilkanaście dni), pamiętając, iż „ogrom zadań stojących przed światem pracy w ramach planu sześcioletniego wymaga wielkiego natężenia sił i stałej czujności, zdolnej wyśledzić każdą możliwość zwiększenia wyników pracy”34. Prezydium ZG ZBiAP pouczało w „Poradniku Bibliotekarza”, że „Ruch współzawodnictwa pracy [...] staje się coraz poważniejszym czynnikiem [...] pogłębiania roli bibliotekarza w socjalistycznym wychowaniu, w upowszechnianiu naukowego światopoglądu marksistowsko-leninowskiego" 35 , i warto w ten sposób uczcić święto ludzi pracy. Ten sam apel ukazał się w „Bibliotekarzu” ${ }^{36}$ - widocznie władze Związku chciały mieć pewność, że dotrze on do wszystkich kręgów pracowników książki. Z okazji rocznicy rewolucji październikowej w Rosji bibliotekarze woj. szczecińskiego wystosowali list do bibliotekarzy radzieckich i wzorując się na nich także podjęli wyzwanie współzawodnictwa ${ }^{37}$. Z kolei pracownicy BN w Warszawie z okazji ósmej „Rocznicy Wyzwolenia Polski i Manifestu PKWN” postanowili włączyć do katalogu nowe pozycje oraz przygotować bibliografię „Wielkiego Proletariatu”38. Jak pisano, bibliotekarze chcą być „ośrodkiem promieniowania najlepszych wzorców sprawności, celowości, i racjonalności wysiłków"39, by móc usprawnić swą pracę. „Poradnik Bibliotekarza” relacjonował, jakie zadania wyznaczyli sobie bibliotekarze podczas majowej Ogólnokrajowej Narady $^{40}$. Planowano między innymi „walkę o nowego czytelnika”, najlepiej wywodzącego się ze wsi lub ze środowiska robotniczego; powinni to być członkowie spółdzielni produkcyjnych, pracownicy PGR-ów, POM-ów, mało i średniorolni chłopi; to wśród nich chciano propagować dobrą książkę ideologiczną i popularnonaukową. Na inne grupy czytelników właściwie szkoda było czasu, a o odpowiednim „składzie socjalnym czytelników” pisano także w tekście $Z$ instrukcyjnej działalności biblioteki wojewódzkiej ${ }^{41}$ napominając, że należy uważnie przyjrzeć się, czy ten skład aby na pewno jest „właściwy”.

Jakie jeszcze zadania sobie stawiano? Biblioteki powszechne - przede wszystkim „werbunek” nowych czytelników, organizowanie nowych filii i punktów bibliotecznych, pomoc w nadzorze nad siecią terenową. Biblioteki naukowe - tworzenie księgozbiorów zakładowych w książnicach

\footnotetext{
34 Kronika. Zobowiązania pierwszomajowe, „Przegląd Biblioteczny” 1952, t. 20, z. 2-3, s. 276.

35 Apel pierwszomajowy, „Poradnik Bibliotekarza” 1951, nr 4, s. 49.

36 Pierwszomajowy apel o wzmożenie współzawodnictwa pracy w bibliotekach, „Bibliotekarz” 1951, nr 1-2, s. 16-17.

37 W rocznicę wielkiej Rewolucji Październikowej. List bibliotekarzy woj. szczecińskiego do bibliotekarzy radzieckich, „Bibliotekarz” 1950, nr 9-10, s. 130-131.

38 Zobowiązania pracowników Biblioteki Narodowej dla uczczenia 8 Rocznicy Wyzwolenia Polski i Manifestu PKWN, „Bibliotekarz” 1952, nr 3, s. 80-81.

39 Kronika. Zobowiazania pierwszomajowe..., s. 276

40 Zadania bibliotekarzy, „Poradnik Bibliotekarza” 1952, nr 8, s. 169-172.

41 Z instrukcyjnej działalności biblioteki wojewódzkiej, „Bibliotekarz” 1951, nr 5-6, s. 75-83.
} 
uniwersyteckich, otwieranie czytelni w niedziele i święta w czasie sesji. Wszystkie placówki - organizowanie wystaw dotyczących życia i działalności B. Bieruta, konstytucji, postępu w nauce polskiej, przeglądu postępowej prasy polskiej i radzieckiej, ruchu robotniczego itp. Ze spraw bardziej przyziemnych - planowano prace porządkowe magazynów, biur, ogrodów bibliotecznych. Pojawiały się akcje nawet tak kuriozalne, jak gromadzenie spinaczy ze starych akt w BN w Warszawie czy sortowanie makulatury. Nasuwa się oczywiście pytanie, czy naprawdę nie można było lepiej wykorzystać wiedzy i umiejętności bibliotekarzy najważniejszej polskiej książnicy?

Mimo tych „czynów” narzekano, że typowe współzawodnictwo zgłosiła tylko sieć bibliotek miejskich w Łodzi, gdyż duże biblioteki, w przeciwieństwie do mniejszych, „nie znalazły jeszcze właściwych sobie form w akcji współzawodnictwa”42. A przecież, jak głosił Bierut, „Nie zrealizujemy rewolucji gospodarczej bez rewolucji kulturalnej”"43, której znaczącym narzędziem są zobowiązania rocznicowe i współzawodnictwo, zachęcające do większego wysiłku. Inne pola, na których bibliotekarze mogli pokazać swe zaangażowanie to na przykład pokierowanie pracą zespołu czytelniczego, pomoc słabszej placówce w opracowaniu księgozbioru czy organizacji wystaw, zapoznanie się z osiągnięciami bibliotek ZSRR, organizacja seminariów dla pracowników bibliotek.

Jeśli chodzi o cel współzawodnictwa, to najogólniej rzecz biorąc, chodziło o podniesienie stanu czytelnictwa masowego, więc Redakcja „Bibliotekarza” podała bibliografię tego zagadnienia, oczywiście z pracami Lenina i Stalina na czele. Pisano:

Głównym elementem współzawodnictwa pracy jest świadomy, twórczy, socjalistyczny stosunek do pracy, właściwy styl pracy wykonywanej z pełnym poczuciem odpowiedzialności i rozumieniem jej polityczno-ideowego znaczenia ${ }^{44}$.

Z czasem jednak zmieniało się oblicze współzawodnictwa, nie tylko w bibliotekarstwie ${ }^{45}$. Początkowo oparte było o ścisłe regulaminy i punktację; mechanicznie zliczano wyniki, co nie zawsze oddawało istotę rzeczy. Potem, jak podkreślała Zofia Rodziewicz, nastąpiło przejście na system oparty na konkretnych, określonych zobowiązaniach, wzorowany na ZSRR, zaproponowany przez CRZZ. Oznaczał on większą samodzielność, dostosowanie do lokalnych warunków, możliwość przedterminowego wykonania zadań ${ }^{46}$. Mimo tych

$42 \quad$ Kronika. Zobowiazania pierwszomajowe..., s. 280.

43 Na 60-lecie urodzin prezydenta Polski Ludowej Bolestaw Bieruta, „Poradnik Bibliotekarza” 1952, $\mathrm{nr}$ 4, s. 65-68.

44 Wytyczne w sprawie wspótzawodnictwa..., s. 43.

45 Por. H. Słabek, O społecznej historii Polski 1945-1989, Warszawa 2009, s. 266 i n. Por. też D. Jarosz, Polacy a stalinizm 1948-1956, Warszawa 2000, s. 69 i n.

46 Z. Rodziewicz, Na nowym etapie wspótzawodnictwa pracy bibliotek, „Poradnik Biblioteka- 
zmian zdawano sobie sprawę z faktu, że w tak specyficznej dziedzinie, jaką jest bibliotekarstwo, niełatwo automatycznie stosować metody z dziedziny przemysłu i naśladować klasę robotniczą.

Jak już wspomniano, z kwestią współzawodnictwa powiązane było takie zjawisko jak racjonalizacja pracy - wypracowanie norm w bibliotekarstwie. Chodziło o zapewnienie kontroli procesu współzawodnictwa. Praca bibliotekarska powinna zostać ściśle skodyfikowana, zmierzona i zważona. Bardzo dokładnie, skoro na szali kładziono czytelnika - jego rozwój i wychowanie w duchu socjalistycznym. Józef Grycz już w 1946 r. pisał, że aby praca bibliotekarza wykonywana była prawidłowo, niezbędne są „odpowiednie przepisy normatywne, regulaminy i instrukcje, trzeba znormalizowanych narzędzi pracy, przede wszystkim jednolitych formularzy" ${ }^{47}$. Niedługo potem te narzędzia, które należało jak najszybciej wypracować, niekoniecznie miały służyć pracy wykonywanej właściwie, a w każdym razie prawidłowość tę zaczęto postrzegać specyficznie, jak widać na przykładach współzawodnictwa przytoczonych w poprzednich akapitach.

Jeśli chodzi o normy pracy wzorem był oczywiście Związek Radziecki, w którym już wcześniej zrozumiano, że „Potężnym środkiem działającym w kierunku wzrostu produkcyjności pracy jest socjalistyczne współzawodnictwo" ${ }^{48}$. To ono śrubowało normy, więc w ZG ZBiAP powołano Komisję Usprawniania i Norm, która rozesłała ankietę mającą na celu zebranie materiałów potrzebnych do zracjonalizowania i usprawnienia pracy bibliotekarskiej $^{49}$. Skoro biblioteka to ,jedno z ważnych ogniw szeregu prac, mających na celu stworzenie nowych socjalistycznych form życia" ${ }^{50}$, to usprawnienie pracy w niej należało uznać za zagadnienie niezmiernie ważne. A miały to zagwarantować właśnie normy. ZBiAP zapewnił, że pamięta o słowach Lenina: „Wydajność pracy, to w ostatecznym rachunku sprawa najważniejsza, sprawa główna dla zwycięstwa nowego ustroju społecznego" ${ }^{\text {"1 }}$.

Co można było poddać normalizacji? Właściwie każdą czynność biblioteczną, ale w tamtej epoce najważniejsze było czytelnictwo masowe: „,czytelnictwo ludu pracującego miast i wsi”. Na wzór radziecki opracowywano plany czytania dla różnych grup społecznych czy zawodowych, w założeniu dostosowane do wykształcenia i poziomu intelektualnego, prowadzące od zagadnień

\footnotetext{
rza" 1952 , nr 7, s. 156-160.

47 J. Grycz, Problemy biblioteczne obecnej doby, „Przegląd Biblioteczny” 1946, t. 14, z. 1, s. 19.

48 Zagadnienie norm pracy w bibliotekach ZSRR, opr. J.M., „Bibliotekarz” 1950, nr 7-8, s. 116 118. S. 318

49 Por. Kronika: Protokół Zebrania..., s. 132. Także Sprawozdanie sekretarza generalnego...,

50 R.F., Zagadnienie usprawnienia i racjonalizacji, „Bibliotekarz” 1949, nr 9-10, s. 152.

51 Sprawozdanie sekretarza generalnego..., s. 341.
} 
prostych do trudniejszych, od lektur na poziomie elementarnym do bardziej wyrafinowanych wykładów ${ }^{52}$. Czytanie nie powinno być spontaniczne, improwizowane, żywiołowe - postanowiono ująć je w karby, zawrzeć w tabelkach i sprawdzić, czy pasuje do założonego wzorca. „Ponieważ takie nagłe przerzucanie się z Rodziewiczówny na France'a, lub z Orzeszkowej na Dostojewskiego jest niedopuszczalne [sic! A.Ł.] z punktu widzenia pewnej rozsądnie kierowanej pracy z czytelnikiem" "53. Zwracano uwagę, że nawet w kształceniu młodzieży brakowało dotychczas planów, było to tylko „czytanie dla czytania”, a przecież żeby przyniosło zamierzony efekt, trzeba je zaplanować i poddać ścisłej kontroli ${ }^{54}$. Zarząd ZBiAP przyznawał: „Borykamy się przy tym z wieloma trudnościami: z trudnością poznania czytelnika, z trudnością doboru właściwej książki, zestawienia właściwych planów czytania na rozmaite poziomy" ${ }^{55}$. Jednak bez planowego działania w tej dziedzinie nie było mowy o uzyskaniu odpowiednich wyników i bibliotekarz jako ideolog nowej kultury musiał stanąć na wysokości zadania.

Obliczano także, ile czasu potrzeba na skatalogowanie jednej książki. Okazało się, że dziesięć minut. A sklasyfikowanie? Według układu dziesiętnego dwucyfrowego zaledwie pięć minut, jak zapisano w regulaminie norm czynności bibliotekarskich w Bibliotece Miejskiej w Gdańsku ${ }^{56}$. Czy bibliotekarze bez oporu przyjmowali narzucane im normy? Oczywiście nie zawsze, więc konstatowano, iż „Pewną rolę odgrywają tu również mniej lub więcej świadome opory, które płyną ze zbyt indywidualistycznej postawy minionej epoki”'57. I podkreślano, że dopiero w socjalizmie wypracowywane są normy pracy (nie tylko w bibliotekarstwie), gdyż przed wojną kodyfikowanie czynności, często prowadzące do rozsądniejszego gospodarowania czasem i siłami pracownika, nie przynosiło nic dobrego: „każde ulepszenie i postęp techniczny przynosiły robotnikom wzmożenie bezrobocia i nędzę" ${ }^{\text {" }}$. Dopiero odgórne

\footnotetext{
${ }_{52}$ Plan czytania, „Poradnik Bibliotekarza” 1951, nr 10, s. 154-157.

53 J. Adler, Z problemów czytelnictwa w domach studenckich, „Bibliotekarz” 1956, nr 11-12, s. 331. Także np.: Wytyczne w sprawie organizacji prasy masowej z czytelnikiem w IV kwartale 1951 roku, „Bibliotekarz” 1951, nr 8-9 s. 128-130; W. Michalska, Wytyczne dla dziatów instrukcyjno-metodycznych wojewódzkich bibliotek publicznych, „Bibliotekarz” 1951, nr 8-9, s. 130-132; A. Łączyńska, O normy pracy dla bibliotekarza (artykut dyskusyjny), „Bibliotekarz” 1954, nr 1, s. 1-12.

54 Por. S. Stochel, Plan czytelnictwa w szkole ogólnokształcacej (uwagi metodyczno-techniczne), „Poradnik Bibliotekarza” 1952, nr 9, s. 199-204.

55 Plenum Zarzadu Głównego ZBiAP, „Przegląd Biblioteczny” 1952, t. 20, z. 2-3, s. 298.

56 Z frontu wspótzawodnictwa pracy, „Bibliotekarz” 1950, nr 7-8, s. 118-119. Por. też I. Morsztynkiewiczowa, O normy czasowe czynności bibliotecznych $w$ bibliotekach naukowych, „Bibliotekarz" 1952, nr 6, s. 179.

57 R. Przelaskowski, Znaczenie zagadnień organizacyjnych i planowania $w$ życiu bibliotek, „Bibliotekarz” 1953, nr 1, s. 8.

58 P. Wasilewski, Racjonalizatorstwo - warunkiem wykonania planu 6-letniego, „Bibliotekarz” 1951, nr 3-4, s. 51.
} 
planowanie i porównywanie pozwala na analizę pracy, usunięcie błędów itp. Dlatego równie ważna jest sprawozdawczość:

W naszym kraju, kraju demokracji ludowej, sprawozdawczość nabiera specjalnej wagi, ponieważ znamienną cechą ustroju socjalistycznego, do którego zdążamy, jest gospodarka planowa na wszystkich odcinkach życia zbiorowego, gospodarka oparta na ścisłej sprawozdawczości ${ }^{59}$,

jako że „Każda biblioteka, nawet najmniejsza, jest ważnym ogniwem w gigantycznym planie budowy socjalizmu" ${ }^{60}$.

Zebrania sprawozdawcze bibliotek to pomysł także zaczerpnięty ze Związku Radzieckiego, a opis tychże pióra Jadwigi Filipkowskiej-Szemplińskiej przywodzi na myśl wzajemne rozliczanie bibliotekarzy i czytelników, choć oczywiście miały one służyć udoskonalaniu pracy jednych i czytelnictwa drugich. Jedno z pytań, które zdaniem autorki warto zadać czytelnikowi (opracowane na podstawie doświadczeń bardziej doświadczonych kolegów radzieckich) to: „Jaką pomoc chcielibyście otrzymać w zakresie kierowania waszym czytelnictwem?”61. Takie spotkanie w BUŁ opisała w „Bibliotekarzu” w 1952 r. Maria Trzcińska konstatując, że narady, tak szeroko stosowane w ZSRR, w Polsce też już na stale weszły do repertuaru działań bibliotek. Chodziło o nawiązanie kontaktu pracowników z czytelnikami, jednak niestety na tej naradzie stawili się przede wszystkim pracownicy naukowi, a zabrakło studentów. Rozmawiano głównie o stosunku do książki, a ściśle rzecz biorąc, o „grzechach” czytelników: kradzieżach, wydzieraniu stronic, podkreślaniu całych stron, przetrzymywaniu wypożyczonych pozycji. A przecież czyny tego typu oznaczały nie tylko przekroczenie czy ominięcie regulaminu; działanie takie uznano wręcz za „objaw niewłaściwego, aspołecznego i nie socjalistycznego [sic! A.Ł.] stosunku do książki"62.

\section{Nowi czytelnicy}

W marcu 1948 r. Rada Państwa podjęła uchwałę o planowej akcji upowszechniania książki i czytelnictwa i oczywiście ZG ZBiAP zgłosił „gotowość ogółu bibliotekarzy polskich do jak najżywszego współudziału ${ }^{63}$ ". Zdaniem władz upowszechnianie czytelnictwa oznaczało automatycznie szybszy rozwój

\footnotetext{
59 E. Pawlikowska, Sprawozdawczość w bibliotece, „Poradnik Bibliotekarza” 1951, nr 1, s. 7. 60 Tamże, s. 8.

${ }^{61}$ J. Filipkowska-Szemplińska, Zebrania sprawozdawcze bibliotek, „Poradnik Bibliotekarza” 1951, nr 3, s. 38.

${ }_{62}$ M. Trzcińska, Narada produkcyjna z czytelnikami w Bibliotece Uniwersyteckiej $w$ Lodzi, „Bibliotekarz” 1952, nr 3, s. 86.

${ }^{63}$ Deklaracja Zarządu Gtównego Zwiąku Bibliotekarzy i Archiwistów Polskich, „Bibliotekarz" 1948, nr 3, s. 34.
} 
kraju, jako że budowa socjalizmu wymagała podnoszenia kwalifikacji - zawodowych, ale może przede wszystkim politycznych. Koniecznych, by zaakceptować wyrzeczenia materialne i pogodzić się ze zmianami zachodzącymi w życiu politycznym i społecznym. Wymagane kwalifikacje najłatwiej można było zdobyć dzięki odpowiedniej lekturze, w związku z tym książki w bibliotekach gromadzono nie zgodnie z upodobaniami czytelników, lecz według odgórnych wytycznych, zgodnie z kluczem ideologiczno-politycznym. Książki służące rozrywce czy mające charakter eskapistyczny były z góry skreślane przez decydentów jako niewarte lektury, gdyż literatura miała nie bawić, lecz tłumaczyć, czym jest socjalizm, jak walczyć o pokój, dlaczego ZSRR jest największym przyjacielem Polski itp. Także pouczać, jak stosować nowoczesne środki produkcji i tym samym przyczyniać się do wzrostu gospodarczego. Książka miała zmienić mentalność ludzi, z analfabetów uczynić świadomych swej roli członków socjalistycznej wspólnoty. Tego właśnie chcieli politycy. W 1954 r. podczas Walnego Zebrania Delegatów ZBiAP przemawiał m.in. wiceminister kultury i sztuki podkreślając, że aby zrealizować tezy IX Plenum, trzeba spopularyzować książkę rolniczą wśród chłopów. Inaczej niemożliwe jest osiągniecie wyższej produkcji ${ }^{64}$.

Według obliczeń historyków Polska miała około 60-letnie zapóźnienie gospodarcze w stosunku do krajów Zachodu po II wojnie światowej (przed wojną zresztą też $)^{65}$. Nic więc dziwnego, że po przejęciu władzy komunistom zależało, by szybko zasypać tę przepaść. W kwietniu 1947 r. podczas posiedzenia plenarnego KC PZPR rozmawiano o przyszłości systemu gospodarczego - chodziło o przyspieszenie wprowadzania socjalistycznej gospodarki, choć jeszcze nie używano tego terminu, mówiono o przeobrażeniach „w duchu demokracji ludowej”. Ale już od lipca 1948 r. nastąpiła tzw. ofensywa socjalistyczna, czyli odgórne, zadekretowane, gwałtowne zmiany stosunków w przemyśle i rolnictwie, mające na celu uspołecznienie gospodarki. Te przemiany w świadomości „najszerszych mas” miały być wspomagane przez książkę, która mogła pomóc „przezwyciężyć w jej czytelniku opory psychiczne wobec zjawisk dnia dzisiejszego, pozostawione przez przeszłość"66. Skoro rolnictwo nie nadążało za przemysłem w podnoszeniu stopy życiowej ogółu ludności, to trzeba było intensywniej szerzyć masowe czytelnictwo na wsi, by chłopi wiedzieli, jak nowocześnie gospodarować i uzyskać większą wydajność z hektara. Zapewniano oczywiście, że w porównaniu z bibliotekarstwem przedwojennym PRL wypada doskonale, jeśli chodzi o liczbę

${ }^{64}$ Protokót obrad Walnego Zebrania Delegatów ZBiAP, „Przegląd Biblioteczny” 1954, t. 22, z. 1, s. 90 .

65 Por. H. Slabek, O spotecznej..., s. 97.

66 Z. Daszkowski, O wspótpracę bibliotek naukowych z siecia bibliotek powszechnych (po konferencji w Jarocinie), „Przegląd Biblioteczny” 1954, t. 22, z. 2, s. 120. 
książek czy czytelników, ale wciąż nie było to czytelnictwo masowe, nad czym ubolewano.

W związku z tym w omawianej epoce sporo czasu i wysiłku poświęcano na uświadomienie bibliotekarzom, że powinni szczególnie intensywnie pracować z czytelnikami dotąd zaniedbanymi, zwykle pozostającymi poza kręgiem ich zainteresowań, mianowicie z chłopami, robotnikami - i z dziećmi. To nieprzypadkowy zestaw: chłopów traktowano jak dzieci ${ }^{67}$, podobnie jak niewykwalifikowanych robotników. Ich lektury miały podlegać szczególnej kontroli, a przypadkowość w ich wyborze traktowano jak zagrożenie. Beztroskie podróże w światy nieznanych książek były wykluczone. Czytelnictwo miało być planowe, celowe, świadome. Żadnej spontaniczności: przestrzegano, że „książka staje się narzędziem wroga $\mathrm{w}$ walce $\mathrm{z}$ socjalizmem budującym nowe, piękniejsze życie" ${ }^{98}$. Bibliotekarz-marksista miał być przewodnikiem, który pozwalałby czytelnikowi na odróżnienie rzeczy postępowych od wstecznych, a więc szkodliwych ${ }^{69}$. Nie można było pozwolić na samodzielne wybory lekturowe osób tak ważnych dla gospodarki, a jednocześnie tak słabo uświadomionych politycznie.

Czytelnika posiadającego kompetencje polityczne i ideologiczne trzeba było po prostu stworzyć. Miał nim być odpowiednio poinstruowany chłop lub robotnik, bo przecież w Konstytucji z 1952 r. zapisano, że władza należy do „ludu pracującego miast i wsi”. Skoro lud miał sprawować władzę (choćby tylko w teorii), to należało zatroszczyć się o jego horyzonty intelektualne. Podkreślano, że „Dziś Państwo Ludowe swą siłę, swój postęp opiera o rosnącą świadomość robotników, chłopów i inteligencji pracującej [...] dba o rozwój czytelnictwa" ${ }^{\prime 70}$, odmiennie niż wcześniej: „Kiedyś w Polsce sanacyjnej raporty policyjne donosiły siedzącym u władzy wyzyskiwaczom, że «najniebezpieczniejsi są ci, którzy dużo czytają»" ${ }^{\text {"’1 }}$. W socjalizmie chłopi czy robotnicy mogli już czytać, ale ich interpretacje zadanych - innych czytać nie powinni - lektur mogły odbywać się jedynie pod czujnym okiem aktywu i bibliotekarza-wychowawcy. Mogli czytać, ale tylko takie pozycje, które pozwalają na „Wychowanie przez książkę nowego człowieka - budowniczego socjalizmu"72.

67 Por. R. Łukaszewska, Głośne czytanie w bibliotece, „Poradnik Bibliotekarza” 1951, nr 6, s. 84-88: dobre nie tylko dla dzieci, ale też dla czytelnika niewyrobionego, początkującego; dzięki niemu ,,bibliotekarz wychowuje czytelników [...] zbliża czytelników do zagadnień światopoglądowych, wprowadza w sposób przystępny na drogę poznania zasad marksizmu - leninizmu", s. 84.

${ }_{68}$ S. Bzdęga, Wspótpraca biblioteki szkolnej z dziecięca biblioteka publiczna, „Poradnik Bibliotekarza" 1953, nr 1, s. 4.

69 Por. K. Wojciechowski, Współczynniki rozwoju czytelnictwa, „Bibliotekarz” 1953, nr 3, s. 71.

70 W. Jagusztyn, List do bibliotekarzy gminnych, „Poradnik Bibliotekarza” 1953, nr 12, s. 270.

71 Tamże.

72 K. Goryńska, Planowanie pracy w bibliotece gminnej, „Poradnik Bibliotekarza” 1952, nr 1, s. 2. 
Na nich więc - chłopach i robotnikach - skupiła się uwaga decydentów, o nich pisano w czasopismach, a bibliotekarze wymyślali sposoby na przyciągnięcie ich do bibliotek. Bo w nowej rzeczywistości bibliotekarz nie czekał na czytelnika, lecz miał obowiązek aktywnie go szukać w zakładzie pracy, w świetlicy, na wczasach ${ }^{73}$, czyli w miejscach, stworzonych dla pracy i odpoczynku nowego człowieka. Szukać i polecać odpowiednią lekturę.

Hasło „upowszechnienia książki” stało się mottem V Zjazdu Bibliotekarzy Polskich w 1948 r. Początkowo chciano upowszechniać ogólnie pojętą twórczość kulturalną $^{74}$, ale już wkrótce zajęto się popularyzacją głównie literatury politycznej. Przede wszystkim wśród chłopów i robotników, gdyż w nich właśnie postanowiono obudzić głód czytania i uczynić z nich nowy typ człowieka, „człowieka przodującego"75. Hasło z pewnością było piękne, jednak by zdobyć czytelnika, najpierw trzeba było w ogóle nauczyć go czytać... W związku z tym 10 VI 1949 r. ZG ZBiAP zgłosił akces do Komitetu Walki z Analfabetyzmem. Nakazano, by koła terenowe organizacji wydelegowały swych przedstawicieli do miejscowych komitetów i „otoczyły opieką bibliotekarską uczestników kursów"76. Ponadto bibliotekarze mieli zadbać o podniesienie poziomu umysłowego ogółu czytelników, nie tylko analfabetów. W $1951 \mathrm{r}$. na łamach „Bibliotekarza” ukazały się wskazówki Ministerstwa Oświaty, jak poradzić sobie ze zwalczaniem analfabetyzmu ${ }^{77}$. Polecano, by otoczyć opieką słuchaczy kursów nauczania początkowego, zorganizować im wycieczki do biblioteki, a nawet rozesłać imienne zaproszenia uświadamiając tym samym, że w bibliotece znajdą książki przydatne do dalszego kształcenia, do pogłębiania świadomości politycznej i ideologicznej, oraz do „godziwej” rozrywki.

Z kolei rok 1949 obwołano rokiem wielkiej „ofensywy bibliotecznej” pod patronatem prezydenta Bieruta ${ }^{78}$. Przewodniczący ZBiAP zapewnił, że Związek wzmoże wysiłki, aby „uprzystępnić książki szerokim masom”. Niedługo potem na łamach „Bibliotekarza” pojawił się artykuł Udział ZB $i$ AP w realizacji ,polityki bibliotecznej "79, w którym narzekano, że akcja upowszechniania i „odpowiedniego wykorzystania” książki rozpoczęła się nie z inicjatywy bibliotekarzy. Lecz nawet jeśli pomysł nie wyszedł od nich, to mogą

73 J. Korpała, Refleksje przed krajowym Zjazdem Bibliotekarzy, „Przegląd Biblioteczny” 1948, t. 16 , z. 3-4, s. 125-138.

74 Tamże, s. 135.

75 Tamże, s. 136.

76 Sprawozdanie sekretarza generalnego..., s. 310 i n.

77 Udzial bibliotek $w$ zwalczaniu analfabetyzmu, „Bibliotekarz” 1951, nr 1-2, s. 13-14. O tzw. kandydatach na czytelników, czyli ogromnej rzeszy 1200000 osób, które czytać nauczyły się dopiero w Polsce Ludowej, sporo pisano w całym roczniku 1954 „Bibliotekarza”.

78 Z życia Zwiazku, „Bibliotekarz” 1949, nr 3-4, s. 57-58.

79 Z. Hryniewicz, Udziat ZB i AP w realizacji ,polityki bibliotecznej”, „Bibliotekarz” 1949, nr 7-8, s. 122-123. 
przynajmniej włączyć się w „budowanie nowego społeczeństwa w nowej Polsce". W tym czasie także Jadwiga Filipkowska-Szemplińska zauważyła, że do roli wychowawczej bibliotekarza „wtargnęła polityka”, choć jeszcze w niewystarczającym stopniu. Na razie to tylko kursy ideologiczne, a to zbyt mało w pracy bibliotekarza polityka powinna koniecznie przeplatać się z kwestiami merytorycznymi, polityką powinny być przesiąknięte codzienne czynności biblioteczne ${ }^{80}$. Jak zresztą bibliotekarze mają zachęcić do korzystania z literatury politycznej, jeśli sami jej nie znają, i nie stosują zasad marksizmu-leninizmu w swej pracy? A przecież podczas Zebrania Delegatów Kół ZBiAP uznano, że „stosunek bibliotekarza do nowej rzeczywistości powinien być nie tylko pozytywny ale i aktywny"; powinien on być opiekunem czytelnika, więc musi do tej roli być przygotowany politycznie; powinien ,pomóc chłopu w jego dążeniu do zdobycia wiedzy"

Jednak narzekano na poziom kadr, stwierdzając, że wychowawcy chłopów i robotników sami pozostawiali wiele do życzenia pod względem ideologicznym - i intelektualnym. Sam fakt, że w „Poradniku Bibliotekarza” musiano pouczać pracowników bibliotek, czym jest kolejność alfabetyczna, mówi sam za siebie ${ }^{82}$. Także podpowiedzi, jakie hasła można wywiesić z okazji różnych rocznic, zamieszczane na łamach tego periodyku (typu: Ksiązka pomoże nam wykonać plan 6-letni; Ksiązka wychowuje i uczy budowniczych socjalizmu; Polska socjalistyczna udostępnia ksiażki szerokim masom), każą się zastanawiać, jaki musiał być poziom bibliotekarzy, skoro zakładano, że sami nie są w stanie wymyśleć najprostszego nawet sloganu? Zamieszczanie takich treści w prasie fachowej rodzi pytanie, czy oznaczało ono brak wiary w możliwości intelektualne kadr bibliotecznych (często osób z tzw. awansu społecznego), czy w ich uświadomienie polityczne ${ }^{83}$ ? Podawano więc Wytyczne $w$ sprawie organizacji imprez $w$ bibliotekach $w$ okresie II kwartału $1951 r^{84}$ (ważne, by w propagandzie czytelnictwa zwrócić uwagę na Plan Sześcioletni, na walkę o pokój); Wytyczne przygotowań do Tygodnia Oświaty, Książki i Pra$s y^{85}$ (dokładne scenariusze, daty, nazwiska itd. warte uczczenia) czy wreszcie Roczne wytyczne do pracy z czytelnikiem ${ }^{86}$ : najważniejsze zadanie to „czuwanie

80 J. Filipkowska-Szemplińska, Zadania Z. B. i A. P. w Polsce Ludowej, „Bibliotekarz” 1949, nr 3-4, s. 38.

81 Kronika: Protokół Zebrania..., s. 129-130.

82 M. Dawidczyńska, Co to jest kolejność alfabetyczna, „Poradnik Bibliotekarza” 1953, nr 1, s. $9-12$.

83 Dzień walki o pokój i socjalizm, „Poradnik Bibliotekarza” 1951, nr 4, s. 51-60.

84 Wytyczne w sprawie organizacji imprez w bibliotekach w okresie II kwartatu 1951 r., „Bibliotekarz" 1951, nr 1-2, s. 10-13.

85 Wytyczne przygotowań do Tygodnia Oświaty, Książki i Prasy, „Bibliotekarz” 1951, nr 1-2, s. $14-16$.

86 Roczne wytyczne do pracy z czytelnikiem, „Poradnik Bibliotekarza” 1952, nr 3, s. 58-63. 
nad jego poziomem ideowo-politycznym"; pomoc w samokształceniu i pomoc $\mathrm{w}$ pracy produkcyjnej, a do tego trzeba „wzmóc propagandę literatury polityczno-społecznej"87.

Aby czytelnictwo przełożyło się na wyższy poziom produkcji rolnej i gospodarczej, musiało być masowe. W ZBiAP stwierdzono, że najważniejsza kwestia pracy bibliotecznej w nowym ustroju, czyli sprawa czytelnictwa, „zwłaszcza na wsi i w środowiskach robotniczych - musi stać się treścią wielu zebrań różnych ogniw naszej organizacji”; zebrania te „powinny być przesycone treścią zarówno fachową jak i ideową"88. Bez pomocy bibliotekarzy trudno będzie przebudować ustrój ekonomiczny, przypominano ${ }^{89}$, i nawoływano wprost: Należy pomóc bibliotekarzom w pracy ideologicznej ${ }^{90}$, aby mogli być „agitatorami i propagatorami słowa drukowanego"; oczywiście słowa o odpowiednim zabarwieniu ideologicznym. Gdyż „Rwący nurt myśli ludzkich, zawartych w książkach, niesie dobro i zło, niesie ziarno i plewy, toczy granity i mul"', a uregulowanie tego nurtu to zadanie bibliotekarza.

Tak więc hasło szerzenia czytelnictwa na dobre zagościło na łamach prasy fachowej. Już w 1949 r. pisano, że oczywistym jest, iż gromadzenie, porządkowanie i udostępnianie to trzy podstawowe kwestie bibliotekarskie, ale teraz częściej trzeba pisać o „szerzeniu czytelnictwa” ${ }^{2}$. Aby dotrzeć do nowych czytelników, niemających nawyku sięgania po słowo pisane, często dopiero co „wyszłych” z analfabetyzmu, należało poszukać nowych dróg, a nie podążać utartymi ścieżkami. Jak czytanie uczynić masowym, jak zdobyć czytelników? Uznano, że należy „zwrócić się frontem do czytelnika”, gdyż „stosunek do czytelnika jest miernikiem uspołecznienia biblioteki i bibliotekarza"93. Dlatego

Zmiana form pracy bibliotek musi przejawiać się w przesunięciu punktu ciężkości z książki na czytelnika, któremu ta książka ma służyć. [...] Organizacja pracy nad czytelnictwem stanowi dziś istotę pracy każdej biblioteki ${ }^{94}$.

87 Por. także Po ogólnokrajowej naradzie bibliotekarzy w sprawie czytelnictwa, „Bibliotekarz” 1952, nr 3, s. 67-73; Konferencja dyrektorów bibliotek wielkomiejskich, „Bibliotekarz” 1953, nr 2, s. $51-52$.

88 Z życia Stowarzyszenia, „Bibliotekarz” 1955, nr 6, s. 190.

89 R. Przelaskowski, Uchwała Prezydium Rzadu w sprawie rozwoju fachowych bibliotek zakładowych, „Bibliotekarz” 1956, nr 5, s. 163-166.

90 J. Podgóreczny, Należy pomóc bibliotekarzom w pracy ideologicznej, „Bibliotekarz” 1953, nr 5, s. 132-133.

91 E. Chełstowski, Rola instrukcyjna i organizacyjna kierownika biblioteki powiatowej, „Bibliotekarz" 1949, nr 3-4, s. 62-64.

92 W.S., Akcja szerzenia czytelnictwa Biblioteki Publicznej m.st. Warszawy, „Bibliotekarz” 1949, nr 9-10, s. 155-157.

93 J. Korpała, Refleksje..., s. 130.

94 M. Manteufflowa, Aktualne problemy w dziedzinie czytelnictwa, „Przegląd Biblioteczny” 1951, t. 19 , z. 3-4, s. 264. 
Stefan Kotarski podczas konferencji krynickiej (3-15 II 1951 r.) perorował, że wielu bibliotekarzy wciąż sądzi, że praca w bibliotece to praca z książką, a tak naprawdę jest to przede wszystkim praca z czytelnikiem ${ }^{95}$. Musi on czuć, że jest kimś ważnym, że nie jest w bibliotece uprzykrzonym petentem, lecz mile oczekiwanym gościem. W nowych warunkach trzeba przerzucić punkt ciężkości z książki na czytelnika - oto najpilniejsze zadanie dla bibliotek, zwłaszcza naukowych, które wciąż mają tendencję do traktowania samych siebie jako niedostępnych „świątyń wiedzy”, zarezerwowanych do wyższych celów niż codzienna obsługa czytelnika.

Aby działania wychowawcze przyniosły skutek, nie wolno tkwić biernie w bibliotece. Niewątpliwie nowatorskim podejściem jest zorganizowanie biblioteki w parku $^{96}$. Na przykład podczas obchodów pierwszomajowych można zorganizować czytelnię i wypożyczalnię na świeżym powietrzu; udzielać rad potencjalnym czytelnikom, pozyskiwać nowych, no i przede wszystkim propagować książkę polityczną. Jana Schubert pisał w tekście Biblioteka pomaga Komisji Poborowej ${ }^{97}$, że bibliotekarze muszą wyjść poza mury biblioteki, na przykład do poborowych z odczytem i pogadanką. Kolejna ciekawa i niecodzienna inicjatywa przedstawiana jako wzór do naśladowania to wystawa książek zorganizowana przez bibliotekarza w Tyszowicach u fryzjera; dzięki niej zdobył aż 30 nowych czytelników ${ }^{98}$. Inna bibliotekarka skarżyła się, że nie mogąc zachęcić mieszkańców do korzystania z biblioteki, wpadła na pomysł, by po seansie kina objazdowego - wyświetlano Dzieci kapitana Granta wspomnieć, że „na naszym punkcie bibliotecznym” posiada książkę Centkiewicza Anaruk. Chłopiec z Grenlandii. Przygotowała wystawkę pt. Przez książki poznajmy świat, dzieci przyszły i zainteresowały się biblioteką, a ona sama też na tym skorzystała, gdyż:

Teraz już wiedziałam jaka jest rola bibliotekarza-oświatowca. Zrozumiałam, że nie wystarczy czekać na czytelnika. Jeśli ten nie zgłasza się do biblioteki - to wó w c z a s k s ią żki muszą wyjść naprzeciw nieuświadomionym jego potrzebom i zainteresowaniom ${ }^{99}$.

Wnosząc z liczby artykułów na temat zdobywania nowych czytelników, a zwłaszcza literatury trudniejszej, współczesnej, politycznej widać, że było to trudne zadanie. A jednocześnie z niego właśnie najczęściej rozliczano bibliotekarzy. Oprócz wyżej wymienionych na łamach prasy fachowej mnożyły

95 Pamiętnik Konferencji Krynickiej 3-15 II 1951. Dyskusja, „Przegląd Biblioteczny” 1951, t. 19 , z. 3-4, s. 279.

96 Z. Rudnicka, Akcja letnia tódzkich bibliotek miejskich, „Bibliotekarz” 1955, nr 4, s. 103.

97 J. Schubert, Biblioteka pomaga Komisji Poborowej, „Poradnik Bibliotekarza” 1953, nr 1, s. $21-22$.

98 J. Ćwiekowa, Przegląd piśmiennictwa, „Bibliotekarz” 1956, nr 2, s. 51.

99 Moje doświadczenia, „Poradnik Bibliotekarza” 1950, nr 4, s. 7. 
się więc kolejne pomysły, jak skusić potencjalnych czytelników do skorzystania $\mathrm{z}$ biblioteki. Jedną z nowych form pracy miał być system komunikacji z czytelnikiem poprzez karteczki, zaproponowany przez jednego pracownika „z terenu" ${ }^{100}$. Mianowicie do wypożyczonej książki należy włożyć karteczkę z pytaniami, sformułowanymi przez bibliotekarza w taki sposób, by zachęcić czytelnika do przemyślenia najważniejszych zagadnień poruszonych $\mathrm{w}$ dziele. Czytelnik razem z książką zwraca karteczkę z odpowiedzią i na tej podstawie bibliotekarz może wnioskować o jego poziomie, zainteresowaniach i stosunku do zagadnień poruszanych przez autora. Najlepsze odpowiedzi mogłyby trafić na odpowiednią tablicę wywieszoną w bibliotece. Ponadto bibliotekarz powinien prowadzić książkę czytelników, w której zapisywałby uwagi na ich temat, takie jak stopień oczytania danej osoby, zainteresowania i odpowiedzi z karteczek. W ten sposób łatwiej byłoby mu pokierować danym czytelnikiem. Redakcja dopowiedziała, że mimo wszystko ta forma dotyczyć może jedynie odbiorców bardziej „,wyrobionych” i lektur, które propagują zagadnienia, uznane za ważne przez bibliotekarza.

Relacjonowane na łamach prasy fachowej formy pracy z czytelnikiem chwilami trącą despotyzmem. W jednym $\mathrm{z}$ artykułów znajdujemy opis, jak powinna wyglądać praca bibliotekarza na przykładzie kierownika filii nr 5 w Bydgoszczy. Najpierw suche dane statystyczne - 2038 czytelników, 3326 woluminów i nagle: „14 księgonoszy spośród członków aktywu obsługiwało teren i docierało do najbardziej biernych i opornych [sic! A.Ł.] czytelników"101. Już kilka lat wcześniej zamieszczano podobne relacje, aktywista biblioteczny opowiadał: „Mamy również na oku opornych wobec książki, a skądinąd pożytecznych i wartościowych ludzi - im będziemy nosić książki, dopóki nie obudzimy w nich nawyku czytania, aby potem skierować ich do biblioteki" ${ }^{102}$. Na dodatek członkowie tego aktywu wyrzucili z biblioteki wszystkie powieści kryminalne, by przypadkiem ktoś nie sięgnął po tę bezwartościową literaturę. Bibliotekarka pochwalała taką postawę, czyli narzucanie odbiorcom lektur konkludując: „Nasi księgonosze wiedzą, że ich funkcja nie polega tylko na mechanicznym dostarczaniu i odbieraniu książek, ale na kierowaniu lekturą czytelnika"103. Księgonosze - mimo apeli zamieszczanych na łamach prasy bibliotekarskiej już w $1950 \mathrm{r}$. o poszukiwanie polskiego odpowiednika tego rosyjskiego terminu nie znaleziono go ${ }^{104}$ - mieli być remedium na ,pewną nieśmiałość” w korzystaniu w biblioteki, widoczną u niektórych potencjalnych czytelników.

100 M. Talerman, Nowa forma pracy czytelnikiem, „Poradnik Bibliotekarza” 1952, nr 1, s. 15-16.

101 A. Narwoysz, Bibliotekarz - wychowawca i społecznik, „Poradnik Bibliotekarza” 1956, nr 1, s. 28.

102 S. Draczko, Nowa forma pracy z czytelnikiem, „Poradnik Bibliotekarza” 1950, nr 5-6, s. 10-11.

103 Tamże, s. 12.

104 Od Redakcji, „Poradnik Bibliotekarza” 1950, nr 5-6, s. 8-9. 
W innym artykule także pisano, że nie ma nic złego w przymuszaniu do czytania. Jeśli ktoś nie chciał wypożyczać książek pomimo, że przynoszono mu lekturę do domu, to bibliotekarz odczytywał mu głośno fragmenty wybranej przez siebie książki, póki ten się nie poddał... ${ }^{105} \mathrm{O}$ przymusie dyskutowano wprost w sekcji czytelnictwa miejskiego w Opolu, narzekając że skoro sprawa czytelnictwa literatury technicznej wygląda źle, to „Aby przyciągnąć młodzież techniczną do czytania, pierwsze spotkania z nią sprowadzamy do przymusu [sic! A.Ł.]”"106. Skoro stawką jest „,uświadomienie społeczne i polityczne chłopstwa pracującego" 107 , to nie można się wahać i stosować półśrodków.

To właśnie księgonosze wydawali się remedium na bierność ewentualnych czytelników. W bibliotece w Szczecinie uznano nawet, że to ,jedyna słuszna droga, które zapewni wykonanie planu czytelnictwa na rok 1952" bliotekarze nie lubili tej metody propagowania czytelnictwa. Dlaczego? Bo jest „formą fatygującą, wymaga pokonywania przestrzeni, dźwigania książek, narażanie się na zmoknięcie i na chłód, na niewygody przy noclegu, a prócz tego powoduje zniszczenie ubrania i obuwia"109. Poza tym mieli opory, by wchodzić do kogoś do domu, bali się odmowy. W związku z tym funkcję księgonoszy nieraz pełnili członkowie aktywu bibliotecznego, przodownicy czytelnictwa, którzy pomagali bibliotekarzom przede wszystkim w ten sposób, że wspierali ich w pracy wychowawczej, dążąc do podniesienia świadomości politycznej mas $^{110}$. Aktywiści w maju 1953 r. podczas II Krajowego Zlotu Przodowników Czytelnictwa opowiadali, jak książka pomogła im zrozumieć politykę PZPR, jak zachęciła do „terminowego i sumiennego" spełniania obowiązków wobec państwa, jak zapewniła lepsze plony i przebudowę życia na wsi ${ }^{111}$. Zacytowano także list tychże przodowników do Bieruta, w którym zapewniali, że „książka stała się powszechnym chłopskim orężem w walce o nową, postępową wieś, w walce o pokój i socjalizm"112. I ci właśnie przodownicy wydawali się idealnym materiałem na księgonoszy - bazując na swych własnych doświadczeniach, zmuszali do czytania innych. Skoro „Bibliotekarz nie

105 Z. Rodziewicz, Na nowym etapie..., s. 156-160.

106 Ogólnopolski Zjazd Bibliotekarzy [Warszawa 16-18 lutego 1956], „Bibliotekarz” 1956, nr 4-5, s. 118-127.

107 Z. Rodziewicz, Narada w sprawie czytelnictwa na wsi, „Poradnik Bibliotekarza” 1953, nr 1, s. $1-3$.

108 W. Regulski, $W$ poszukiwaniu nowych dróg rozwoju czytelnictwa. $Z$ doświadczeń wojewódzkiej biblioteki publicznej w Szczecinie, „Bibliotekarz” 1956, nr 2, s. 39.

109 Tamże.

110 F. Bursowa, Przodownicy czytelnictwa, „Poradnik Bibliotekarza” 1951, nr 1, s. 3-6.

111 J. Makaruk, Bibliotekarze i kierownicy punktów bibliotecznych na II Krajowym Zlocie Przodowników Czytelnictwa, „Poradnik Bibliotekarza” 1953, nr 9, s. 204-206; II Krajowy Zlot Przodowników Czytelnictwa, „Bibliotekarz” 1953, nr 3, s. 65-68.

112 II Krajowy Zlot..., s. 69. 
może już poprzestać na samej technice bibliotecznej, ale winien się zwrócić do pedagogiki w nowym, rewolucyjnym znaczeniu tego słowa" ${ }^{113}$, to aktyw czytelniczy mu w tym pomoże. W kolejnym roku w Meldunku III Krajowego Zlotu Przodowników Czytelnictwa dla Pierwszego Sekretarza KC PZPR Obywatela Bolesława Bieruta ${ }^{114}$ przodownicy chwalili się, że przekroczyli normy udziału w konkursach czytelniczych. Zakładano udział 500 tysięcy chłopów pracujących, a zgłosiło się 612 tysięcy. Przeprowadzono 100 tysięcy dyskusji nad książkami i złożono 500 tysięcy wypowiedzi pisemnych.

Ogólnopolska Narada Działaczy Kultury i Sztuki w 1952 r. zakończyła się konkluzją, iż „ofensywa kulturalna powinna ogarnąć masy chłopskie” W jakim celu? Jak już wspominano, chciano w ten sposób nakłonić chłopów do wydajniejszej produkcji oraz do wstępowania do spółdzielni produkcyjnych. Innymi słowy chodziło o wdrożenie ,na odcinku bibliotecznym” wytycznych PZPR dotyczących podniesienia wydajności rolnictwa, o spopularyzowanie wśród chłopów książki rolniczej ${ }^{116}$. Bo w 1954 r. twierdzono, iż wciąż, niestety, „Prości rolnicy nie przywykli jeszcze w swej masie do czytania książek fachowych. Pierwsze tedy książki rolnicze winny ich wciągnąć do lektury, zachwycić swą praktycznością i powabem [sic! A.Ł.]"117. Polityczna orientacja mieszkańców wsi nie była taka, jakiej życzyłaby sobie nowa władza. Zdaniem decydentów chłopi pilnie potrzebowali uświadomienia politycznego i ideologicznego, by zrozumieć, że w nowym ustroju będzie im się żyło lepiej, by wyzbyć się obaw przed kolektywizacją i zaakceptować wzory płynące z ZSRR. Poruszano te kwestie choćby podczas konferencji w sprawie organizacji bibliotek i czytelnictwa na wsi zorganizowanej w Warszawie w 1952 r. Na podstawie wytycznych VII Plenum KC PZPR w sprawie „zacieśnienia więzi między

113 L. Kuciel, Aktyw czytelniczy pomaga Bibliotece Miejskiej we Wrocławiu, „Bibliotekarz” 1953, nr 1, s. 17. Por. także Z. Kowalska, Notatka o aktywie czytelniczym w Bibliotece SGPiS, „Bibliotekarz” 1953, nr 1, s. 15-17 czy P. Wasilewski, Koło Przyjaciół Biblioteki, „Bibliotekarz” 1952, nr 3, s. 81-82.

114 Meldunek III Krajowego Zlotu Przodowników Czytelnictwa dla Pierwszego Sekretarza KC PZPR Obywatela Bolesława Bieruta, „Bibliotekarz” 1954, nr 3, s. 65-66.

115 Cz.K., Jednolity front kultury (po Ogólnopolskiej Naradzie Działaczy Kultury i Sztuki), „Bibliotekarz" 1952, nr 5, s. 129-130, zob. także Z. Daszkowski, O wspólpracę..., s. 120-125. Por. też A. Chamera-Nowak, Książki, biblioteki i bibliotekarze na wsi polskiej w okresie stalinizmu w świetle dokumentów Centralnego Urzędu Wydawnictw Przemystu Graficznego i Księgarstwa, ,Rocznik Bibliologiczno-Prasoznawczy" 2013, t. 5 (16), s. 15-30; D. Jarosz, Książki pod strzechy. Z badań nad politycznymi uwikłaniami czytelnictwa na wsi polskiej w latach 1949-1956, „Z Badań nad Książką i Księgozbiorami Historycznymi” 2008, t. 2, s. 37-53.

116 J. Grabowska, Biblioteki przyczyniaja się do podniesienia gospodarki rolnej i hodowlanej (Z doświadczeń biblioteki woj. lubelskiego), „Bibliotekarz” 1955, nr 5, s. 130-132. Por. także tematy poruszane przez wiceministra kultury i sztuki podczas Walnego Zebrania Delegatów ZBiAP, zob. Protokół Obrad..., s. 88.

117 K. Wojciechowski, Czy dobrze udostępniamy książki i czasopisma rolnicze, „Bibliotekarz” 1954 , nr 2, s. 36 . 
miastem a wsią, podniesienia gospodarki wiejskiej i rozbudowy pracy polityczno-masowej na wsi" sformułowano zadania dla bibliotek uznając, że mają spełniać zasadniczą rolę wychowawczą i polityczną, czyli propagować światopogląd oparty na marksizmie-leninizmie. Biblioteki, organizując ofensywę kulturalną na wsi powinny wykorzystać partyjny aktyw wiejski i organizacje masowe. Podczas konferencji podkreślano, że „najbardziej krzepiące na duchu były wystąpienia kolegów bibliotekarzy gminnych [...] wykazujące właściwą postawę polityczną, znajomość zagadnienia i wielki entuzjazm w pracy"118 i cieszono się, że ,„...] rośnie kadra pełnowartościowych, świadomych, bojowych pracowników na tym niesłychanie ważnym odcinku frontu kulturalnego, jakim są biblioteki gminne" 119 .

Cały czas jednak zastanawiano się, jak przybliżyć chłopom książkę i prasę? Jak zachęcić ich do korzystania z bibliotek? Oprócz dostarczania lektur do domu przez księgonoszy jedną z metod najczęściej opisywanych na łamach czasopism zawodowych były konkursy czytelnicze. Przekonywano, że przyczynią się do wzrostu liczby czytelników i rozwoju czytelnictwa książek rolniczych, co skutkować będzie podniesieniem wydajności gleby i hodowli zwierząt ${ }^{120}$. Pisano, że chodzi o to, by książka stała się niezbędnym przedmiotem w każdym wiejskim domu. Romana Łukaszewska radziła, Jak dobierać książki do czytania $w$ „Konkursie czytelników wiejskich”121, bo „postępowa” książka może zrobić dużo dobrego. Nie wolno więc sięgać po pierwszą lepszą pozycję, która po prostu jest pod ręką. Lektury te powinny skłaniać do dyskusji nad zagadnieniami typu: ,Jak kapitaliści wyzyskiwali ludzi pracy i jak z tym wyzyskiem walczyli robotnicy?”, „Jakie zmiany zaszły w życiu wsi?’ itp. Ponadto konkursy muszą zostać dobrze rozpropagowane, na przykład Jan Makaruk z Nowego Tomyśla zalecał, by na każdym zebraniu w gminie czy gromadzie, bez względu na ich tematykę, pojawiał się bibliotekarz, tłumacząc ideę konkursu, rozdając formularze i zachęcając do uczestnictwa ${ }^{122}$. Jeśli książka ma stać się ,powszechnym chłopskim orężem w walce o nową postępową wieś" ${ }^{23}$, to nie ma innego wyjścia, jak tylko zaangażować się w swą pracę

118 Konferencja $w$ sprawie organizacji bibliotek i czytelnictwa na wsi, „Bibliotekarz” 1952, nr 6, s. 163.

119 Tamże.

120 F. Bursowa, Z doświadczeń konkursu czytelników wiejskich, „Bibliotekarz” 1954, nr 2, s. 33-35; Z życia Stowarzyszenia, „Bibliotekarz” 1955, nr 9, s. 285; A. Wierzbicka, Czytelnik czekatrzeba do niego trafić, „Bibliotekarz” 1955, nr 11, s. 324-328.

121 R. Łukaszewska, Jak dobierać książki do czytania w „Konkursie czytelników wiejskich”, „Poradnik Bibliotekarza” 1953, nr 11, s. 241-251.

122 J. Makaruk, Powiat Nowy Tomyśl w IV etapie konkursu czytelników wiejskich, „Bibliotekarz" 1953, nr 6, s. 178-179.

123 Konkurs czytelników wiejskich IV etap 22.VII.1953-22.VII.1954, „Poradnik Bibliotekarza” 1953, nr 9, s. 194. 
w stu procentach, realizując hasło apelu uchwalonego przez krajową naradę aktywu czytelniczego: „Ponieśmy książkę w masy chłopskie” ${ }^{24}$. Napominano, że dobry bibliotekarz to taki, który posiada „Umiejętność wżycia się w środowisko, przejęcia się jego żywą problematyką" 125 i zamiast skupiać się na czynnościach czysto technicznych, gros czasu poświęca kontaktom z czytelnikami. To dzięki takim bibliotekarzom „Na wsi coraz więcej jest książek, w każdej chałupie chłopi siedzą i czytają książki”, jak stwierdzono podczas Ogólnopolskiego Zjazdu Bibliotekarzy w 1956 r. ${ }^{126}$

Druga grupa, która doczekała się szczególnego zainteresowania ze strony bibliotekarzy w omawianym czasie, to robotnicy. Już w 1948 r. pisano o konieczności zadbania o ich czytelnictwo, gdyż od poczytności książki technicznej zależeć miał rozwój przemysłu i rzemiosła ${ }^{127}$. Jednak kilka lat później narzekano, że wciąż dziedzina czytelnictwa technicznego leży odłogiem ${ }^{128}$. Dlaczego? Uznano, że może winna jest nieodpowiednia polityka czytelnicza, czyli zajmowanie się chłopami kosztem robotników:

Tak się jakoś w polityce kulturalnej układa, że więcej uwagi poświęca się wsi, aniżeli życiu kulturalnemu wśród robotników. Fakt ten można zaobserwować szczególnie wtedy, gdy mówi się o czytelnictwie. Może to wynika z przeświadczenia, że klasa robotnicza jest bardziej świadoma i nie potrzeba tu nikogo agitować dla książki ${ }^{129}$.

Ponadto narzekano, że w przedsiębiorstwach brak bibliotek i bibliotekarzy. A jeśli nawet są tam księgozbiory, to niedostosowane do profilu czytelnika, do jego potrzeb zawodowych. Czasem w zakładach pracy jest kilka różnych biblioteczek - tzw. świetlicowe, Klubów Techniki i Racjonalizatorstwa, NOT, techniczne. Rozpraszanie sił i środków skutkuje tym, że wszystkie te zbiory są bardzo ubogie. Apelowano więc $O$ rozwój czytelnictwa w zakładach produkcyjnych ${ }^{130}$; O stała i planowa politykę nabytków w bibliotekach związków zawodowych ${ }^{131}$; o ,przyspieszenie realizacji Uchwały Prezydium Rządu z dnia 24.IX.1953 r. o bibliotekach fachowych jako sprawy niezmiernie ważnej dla postępu technicznego" ${ }^{132}$. Napominano, że bibliotekarz powinien wiedzieć,

\footnotetext{
124 J. Ćwiekowa, Przegląd..., s. 47.

125 Ogólnopolski Zjazd Bibliotekarzy..., s. 111.

126 Tamże, s. 89-151.

127 J. Skarżyńska, Jedno z ważnych zadań biblioteki w planie trzyletnim, „Bibliotekarz” 1948,
} nr 1-2, s. 4-6.

128 M. Mikołajski, Zadania technicznych bibliotek zakładowych, „Bibliotekarz” 1952, nr 2, s. $42-45$.

129 F. Grabowski, Z książka do robotników, „Bibliotekarz” 1955, nr 11, s. 337.

130 M. Mikołajski, O rozwój czytelnictwa w zakładach produkcyjnych, „Bibliotekarz” 1953, nr 5, s. 141-143.

131 M. Skwarnicki, O stała i planowa politykę nabytków w bibliotekach związków zawodowych, „Bibliotekarz” 1956, nr 1, s. 2-5.

132 Ogólnopolski Zjazd Bibliotekarzy..., s. 118-127. 
co czyta robotnik (i dlaczego tak mało), co go interesuje, jak korzysta z kultury, gdyż dopiero wtedy będzie mógł mu zaproponować odpowiednie pozycje. Może to zrobić na przykład podczas spotkań urządzanych w hotelach robotniczych; to bardzo dobra i wygodna forma propagowania czytelnictwa w tej grupie. Maria Tarnowska zaproponowała, by przedyskutować z mieszkańcami hotelu Opowieść o prawdziwym człowieku Borysa Polewoja ${ }^{133}$, poruszając przy okazji problem nieustannej walki o pokój i wiecznej miłości do Stalina. Z kolei R. Łukaszewska postulowała czytanie tekstów o Hucie Częstochowa z okazji rocznicy uruchomienia pierwszej budowli Planu Sześcioletniego, radząc, by „Po przeczytaniu rozdziałów bibliotekarz, nawiązując do ich treści oraz do swojej pogadanki, postarał się wywołać swobodną pogadankę z zebranymi" "134, przybliżając tak ważny temat, jakim jest współzawodnictwo pracy.

Jednak czuwanie nad lekturami jedynie dorosłych czytelników mijało się z celem, bo przecież dzieci, ta „przyszłość narodu”, wkrótce także miały wyrosnąć na robotników i chłopów. W związku z tym jak najszybciej należało „przysposabiać już swych najmłodszych obywateli do nowych czekających ich zadań” 135 . Należało im „wpajać orientację w zagadnieniach politycznych i społecznych". W tamtym okresie dzieciństwo nie miało być czasem beztroski, zabawy, niewinności i naiwności - politycznej czy społecznej. Jak podkreślano, książki w poprzedniej epoce miały za zadanie „oderwać dziecko od codziennych niepokojących zagadnień, od walki o chleb, i przygotować je na przyszłego pokornego niewolnika kapitalistycznej eksploatacji" ${ }^{136}$. A w PRL? Literatura miała „stworzyć dzielnego obywatela”, „zrobić z niego bojownika o socjalizm”137. Dlatego stwierdzono stanowczo: „Usuwamy z bibliotek bezwartościowe, bzdurne «powieści dla panienek» i cowboyskie sensacje deprawujące młodego czytelnika"138. Trzeba pilnować, by dziecko nie szukało w książce „marzycielstwa i sentymentalizmu”, lecz czytało to, co „przemawia do sił twórczych". Według angielskich badań czytelniczych, jak relacjonowano, jedenastolatkowie w kapitalizmie najbardziej pragną: bogactwa, pożywienia, władzy nad otoczeniem, rozrywek, wygód itp. A w ZSRR? „Pragną one głównie być

133 M. Tarnowska, Mieszkańcy hotelu robotniczego dyskutuja o „ludziach stalinowskich” w oparciu o „Opowieść o prawdziwym człowieku” Borysa Polewoja, „Poradnik Bibliotekarza” 1953, nr 11, s. 260-264.

134 R. Łukaszewska, Czytamy o hucie „Częstochowa”, „Poradnik Bibliotekarza” 1953, nr 5, s. $108-113$.

135 B. Groniowska, Zadania dziecięcych bibliotek publicznych, „Bibliotekarz” 1949, nr 11-12, s. 180. W związku z nowymi zadaniami już w 1947 r. postanowiono w szkolnictwie ocenić przydatność lektur i podręczników pod kątem ideowo-politycznym i specjalne komisje do września zweryfikowały 2600 pozycji, wiele z nich kwalifikując do wymiany, ewentualnie poprawek.

136 N. Łamkow, Literatura dziecięca w Bułgarii, przełożył K.J., „Bibliotekarz” 1951, nr 7, s. 104.

137 Tamże.

138 Od Redakcji, „Bibliotekarz” 1951, nr 8-9, s. 113. 
pożytecznymi członkami społeczeństwa radzieckiego"139. Skąd ta różnica? Właśnie dzięki książkom, dzięki odpowiednim lekturom oczywiście.

Już w 1947 r. odbył się „I-szy Ogólnopolski Kongres w sprawie literatury dla dzieci"140, na którym pojawiły się głosy, że współczesna literatura dziecięca nie spełnia oczekiwań władz, gdyż w ogóle nie opowiada o życiu na wsi, a o bytowaniu w mieście mówi w taki sposób, że ukazuje nędzę robotnika, zamiast podkreślać wartość jego pracy. Literatura dla dziewcząt to już w ogóle jedno wielkie ,zakłamanie i łatwizna”. A wznawiane przedwojenne pozycje dają fałszywy obraz dawnego społeczeństwa, w którym wszyscy rzekomo byli zamożni. Także podczas „Krajowej konferencji w sprawie bibliotek dziecięcych" w 1952 r. podkreślano konieczność pojawienia się na rynku wydawniczym nowych lektur: o ludziach ideowych, walczących o nowy świat, o masach pracujących itp., gdyż czytelnictwo dzieci miało wiązać się z celami wychowawczymi państwa i PZPR ${ }^{141}$. Podawano więc w prasie fachowej spisy lektur, mające ułatwić pracownikom bibliotek ,właściwe wychowanie ideologiczne naszej młodzieży przez dostarczenie jej przemyślanej i rozumnie dobranej lektury"142. Apelowano: Poświęcajmy więcej uwagi wychowaniu młodzieży, gdyż należy „chronić ją przed wpływem wroga”, m.in. dzięki odpowiedniej lekturze $^{143}$. Książka kapitalistyczna jest bardzo niebezpieczna, ponieważ powstaje tylko po to, by „deprawując, zapewnić zysk nieuczciwym wydawcom” "144, zamiast wychowywać, jak ta socjalistyczna, która zapewnia ,przygotowanie młodzieży do aktywnego udziału w budownictwie społeczeństwa socjalistycznego, wychowanie jej w głębokim patriotyzmie, internacjonalizmie i moralności socjalistycznej”"145. Podkreślano, że w krajach „zmarszalizowanych” widać zalew złej literatury dla dzieci, czyli tzw. comics, przestrzegano przed tym gatunkiem na łamach „Bibliotekarza”. Dlaczego? Nie ma w tej literaturze żadnych wartości wychowawczych; zero moralności, ani śladu humanitaryzm. W komiksach dzieci znajdą tylko zbrodnię i okrucieństwo, jak przestrzegano ${ }^{146}$. To dalekie od ideałów, jakie chciało swoim obywatelom, także tym najmłodszym, wpoić państwo socjalistyczne. Niestety w polskich bibliotekach wciąż zbyt mało

139 L.B., Czytelnictwo dziecięce zagranica, „Bibliotekarz” 1950, nr 9-10, s. 152.

140 K. Suffczyńska, M. Wernerówna, I-szy Ogólnopolski Kongres w sprawie literatury dla dzie$c i$, „Bibliotekarz” 1947, nr 5-6, s. 99-101.

${ }^{141}$ Krajowa konferencja w sprawie bibliotek dziecięcych, „Bibliotekarz” 1952, nr 3, s. 79-81.

142 Ksią̇ki dla dzieci i młodzieży, „Poradnik Bibliotekarza” 1950, nr 10-11, s. 5; Młodzież w literaturze polityczno-społecznej, opr. J.B., „Poradnik Bibliotekarza” 1952, nr 2, s. 43-50.

143 Poświęcajmy więcej uwagi wychowaniu młodzieży, „Bibliotekarz” 1955, nr 2, s. 33-34.

144 L. Bandura, Z zagranicznych badań nad czytelnictwem dzieci i młodzieży, „Bibliotekarz” 1950, nr 5-6, s. 83.

145 M. Michałowska, Wspótpraca biblioteki ze szkoła (Z doświadczeń Biblioteki Miejskiej im. L. Waryńskiego w Lodzi), „Bibliotekarz” 1955, nr 2, s. 34.

146 L.B., Walka ze zła literatura, „Bibliotekarz” 1952, nr 1, s. 22. 
było odpowiedniej literatury dla dzieci i młodzieży; literatury współczesnej, postępowej, socjalistycznej. Należało wziąć przykład z NRD, gdzie starając się nadrobić tego typu braki, organizowano konkursy na książkę dla dzieci, której tematykę stanowić miały walka o pokój i zjednoczenie Niemiec czy stosunek człowieka do pracy - główną nagrodę zdobył pewien agronom za opowiadanie Budujemy najpiękniejsze todzie, ,prześwietlone [...] aktualnymi zagadnieniami politycznymi"147.

\section{Kontrola lektur}

Pomimo selekcji zbiorów w bibliotekach wciąż sporo było pozycji przedwojennych, czyli burżuazyjnych i reakcyjnych, przeznaczonych zarówno dla dorosłych, jak i dla dzieci oraz młodzieży. I to one były, nad czym ubolewano, najbardziej poszukiwane przez czytelników. Jak radzono sobie z tym problemem? Po pierwsze, można je było usunąć z katalogu - zresztą rzadko istniejącego, a jeśli nawet, to nieczęsto udostępnianego czytelnikowi. Po drugie, można było fizycznie usunąć nieprawomyślne lektury z księgozbioru. Po trzecie, jeśli już nawet tego typu książki nie zostały wyeliminowane z księgozbioru, a ich opisy z katalogu, można było ściśle kontrolować wypożyczenia czytelników, podsuwając im jedynie odpowiednie ideologicznie pozycje.

Jeśli chodzi o pierwszy sposób utrudniania kontaktu z niepożądanymi pozycjami, to zdawać by się mogło, że sporządzanie katalogów czy bibliografii stanowi zajęcie wolne od ideologicznych konotacji. Nic bardziej mylnego. Bibliografia „kluczem do ujawniania bogactw książkowych”148? Z „Przeglądu Bibliotecznego" można było dowiedzieć się, że to błędny pogląd. Skoro książka „to skuteczny sprzymierzeniec lub groźny wróg”"149, to „Biblioteki, jako stacje przekaźnikowe nauki, rozpylające wiedzę w tysiącach egzemplarzy dzieł - musiały pójść po tej samej linii, którą wytyczono nauce" ${ }^{150}$. Czyli skupić się na jej zawartości ideologicznej, a nie merytorycznej. Dlatego przy

147 L.B., Powstanie nowej literatury dziecięcej w Niemieckiej Republice Demokratycznej, „Bibliotekarz" 1951, nr 12, s. 172.

148 G. Fonotow, O bolszewicka partyjność $i$ związek z praktyka $w$ pracach teoretycznych nad bibliografia, [przeł. T. Remer], „Przegląd Biblioteczny” 1951, t. 19, z. 1-2, s. 4. Por. też A. Łuszpak, Obraz katalogów rzeczowych na łamach polskich czasopism bibliotekarskich $w$ okresie stalinowskim, „Z Badań nad Książką i Księgozbiorami Historycznymi” 2016, t. 10, s. 295-315 oraz taż, Katalogi rzeczowe w stużbie ideologii (na przykładzie Biblioteki Uniwersyteckiej we Wrocławiu w latach pięćdziesiatych XX wieku), [w:] Nie po myśli władzy. Studia nad cenzura i zakresem wolności słowa na ziemiach polskich od wieku XIX do czasów współczesnych, pod red. D. Degen, M. Żyndy, Toruń 2012, s. 249-262.

149 K. Remerowa, Aktualne zagadnienia $w$ zakresie opracowywania zbiorów bibliotecznych, (wraz z dyskusja), „Przegląd Biblioteczny” 1951, t. 19, z. 3-4, s. 243.

150 Tamże, s. 247. 
sporządzaniu katalogów należało wystrzegać się „burżuazyjnego formalizmu”, za który skrytykowano jedną z bibliotekarek:

Działy wypracowane przez kol. Łączyńską nie odpowiadają potrzebom wychowania socjalistycznego. Projektowany podział grzeszy formalizmem i tradycyjną apolitycznością, gdyż nie ma przecież w literaturze pięknej książek, które nie byłyby apolityczne [sic! A.Ł.]. Zagadnienia psychologiczne i pedagogiczne ściśle wiążą się z politycznymi, co każdy bibliotekarz powinien już rozumieć ${ }^{151}$.

Selekcja zbiorów pod kątem politycznym wydawała się naturalnym sposobem zapobieżenia czytelnictwu pozycji „niewłaściwych”. Usuwanie sprzed oczu i rąk niewykształconego, niewyrobionego politycznie czytelnika lektur reakcyjnych uznano za doskonały sposób kontrolowania czytelnictwa. Redakcja „Bibliotekarza” już w 1949 r. przestrzegała:

My, bibliotekarze i archiwiści, pracujemy w dziedzinie narażonej również, a może nawet szczególnie - na penetrację fałszywej lub wrogiej ideologii. Ze szczególną czujnością winniśmy kontrolować nasze księgozbiory i wykazywać wielką dbałość i uwagę przy ich udostępnianiu ${ }^{152}$.

W 1948 r. nie sprecyzowano jeszcze, które książki prezentują ,fałszywą" ideologię, które są „błędne”. Józef Korpała pisał jedynie, że bibliotekarz powinien „uczyć czytać dobrą książkę i zapobiegać rozpowszechnianiu się lektury książek siejących zamęt lub błędne poglądy" ${ }^{153}$, choć już podkreślał, iż bibliotekarstwo musi „zbliżyć się do ideologii i światopoglądu klasy robotniczej ku socjalizmowi" ${ }^{154}$. Zaraz potem pojawiły się konkretne wytyczne, choćby w tekście Zastosowanie uchwat III Plenum KC PZPR w pracy ZBiAP:

Obfite zaopatrzenie bibliotek w literaturę piękną naprawdę realistyczną, budującą nową optymistyczną, socjalistyczną świadomość oraz w literaturę wprowadzającą w światopogląd marksistowski i w dzieła oparte na tym światopoglądzie - oto co powinno wyprzeć z półek i z zamiłowań czytelników „obojętną” czy szkodliwą przestarzałą literaturę ${ }^{155}$.

Wtórowała temu J. Filipkowska-Szemplińska, podkreślając, że dobór książek to sprawa najwyższej wagi, gdyż:

Jakże często zestawy książek w bibliotece zawierają dzieła tradycyjnie uznane za klasyczne, niezastąpione tylko dlatego, że są poczytne i żądane przez czytelników. Zestaw książek [...] nie zawsze jest uważnie przejrzany pod kątem widzenia jego dzisiejszej przydatności ${ }^{156}$.

151 M. Talerman, Głos w dyskusji nad katalogiem beletrystyki, „Bibliotekarz” 1952, nr 1, s. 22

152 Redakcja, Zastosowanie uchwat III Plenum KC PZPR w pracy ZBiAP, „Bibliotekarz” 1949, nr 11-12, s. 179.

153 J. Korpała, Refleksje..., s. 136.

154 Tamże.

155 Redakcja, Zastosowanie uchwat..., s. 179.

156 J. Filipkowska-Szemplińska, Zadania Z. B. i A. P. ..., s. 39. 
W dodatku „Najtrudniej jednak jest wykryć i usunąć cały szereg wydawnictw beletrystycznych, pozornie nieszkodliwych, które przesiąknięte są ideałami świata burżuazyjnego, kultem dla nierobów i snobizmem”157. W „Poradniku Bibliotekarza” ostrzegano, że w czasach ,przebudowy ustroju społeczno-politycznego" należy usuwać literaturę małowartościową i społecznie szkodliwą, czyli książki „obce ideologicznie, przestarzałe pod względem naukowym, szkodliwe wychowawczo"158. To nieuniknione, skoro „Zadaniem biblioteki jest wychowanie i przygotowanie szerokich mas ludowych do pracy nad budową socjalizmu w Polsce"159.

Jednak selekcja napotykała opory. Anonimowa bibliotekarka wspominała, że brała udział w kilku akcjach tego typu i zauważyła, że o ile walka z książką antykomunistyczną udaje się w bibliotekach całkiem nieźle, to niestety trudno się pozbyć romansów. A przecież, konkludowała, awans kopciuszka na księżniczkę to nie jest model, jakiego pragnąć powinny kobiety w socjalizmie, to jedynie ,przeżytek starego ustroju" ${ }^{160}$. Czym więc zastąpić Marię Rodziewiczównę? Problem niełatwy, poruszony też w cyklu Janiny Skarżyńskiej Między nami, publikowanym w „Poradniku Bibliotekarza”, w konwencji rozmów między dwiema bibliotekarkami Zosią i Wandą (mniej i bardziej uświadomioną politycznie). Romanse z pewnością pokazują złe wzorce, osłabiają wolę działania; podkreślano, że „pokora i posłuszeństwo to nie są nasze zalety”; „my musimy mieć dzi e $1 \mathrm{ny} \mathrm{ch}$, en ergicznych $1 \mathrm{udzi}$, karnych lecz umiejących czynnie bronić swych przekonań" ${ }^{161}$. Rodziewiczówna jest poczytna, jednak w swych powieściach potępia wszystko, co rosyjskie na fali „popowstaniowej nienawiści”, trzeba więc walczyć z taką literaturą, zwłaszcza że ,propaganda zagraniczna budzi nienawiść do Związku Radzieckiego, podżega do wojny i wypowiada otwartą walkę obozowi Pokoju" "162. Co więc robić, gdy czytelnik żąda takich reakcyjnych powieści? Trzeba starać się zaspokajać głód czytelniczy „literaturą socjalistyczną, wartościową, potrzebną i dostosowaną do możliwości każdej grupy czytelników"163. Trzeba starać się jak najszybciej zaopatrzyć biblioteki w postępową literaturę piękną. Nie można „iść na skróty” i oferować czytelnikowi książkę lekką, „wypraną z wszelkiej ideologii”. Tak robią niektórzy bibliotekarze, wypożyczając jedną pozycję tego typu, a drugą o zabarwieniu ideologicznym. Pierwsza

157 Tamże.

158 Usuwanie książek z biblioteki, „Poradnik Bibliotekarza” 1950, nr 5-6, s. 19-20.

159 J. Filipkowska-Szemplińska, O książkach szkodliwych, „Poradnik Bibliotekarza” 1950, nr 10-11, s. 13.

160 Zofia P. z Warszawy, Listy z terenu, „Poradnik Bibliotekarza” 1950, nr 12, s. 15.

161 J. Skarżyńska, Między nami, „Poradnik Bibliotekarza” 1951, nr 5, s. 71.

162 Tamże.

163 K. Wojciechowski, Potrzeby czytelnictwa masowego, „Bibliotekarz” 1950, nr 5-6, s. 66. 
ma za zadanie przyciągnąć do biblioteki, druga wychowywać. Ale taki kompromis to fałszywa droga, przestrzegano bibliotekarzy. Trzeba szukać literatury atrakcyjnej i ciekawej, lecz nasyconej socjalistycznymi treściami i przepojonej ideologicznym duchem. Polecano dzieła Stalina, innych klasyków socjalizmu, dzieła o bratnich krajach - NRD czy Chinach Ludowych. Oczywiście nie można zapominać, że książki czytelnikowi należy dobrać zależnie od jego wieku, przygotowania $\mathrm{i}$ - przede wszystkim - wyrobienia politycznego ${ }^{164}$.

Nie tylko romanse i przedwojenna beletrystyka mogły zaszkodzić, także kryminały i powieści „cowboyskie” były na cenzurowanym:

Musimy sobie jasno zdać sprawę, że powieści tego typu nie mogą być tolerowane w naszych bibliotekach, mających na celu wychowanie czytelnika, podnoszenie jego poziomu ideologicznego i społecznego oraz dostarczenie mu godziwej rozrywki ${ }^{165}$.

Bohater powinien być nie tylko „mocny ciałem”, ale i pozytywny. Pojawiły się głosy, że zbyt długo tolerowano takie pozycje (zwykle przedwojenne). Bibliotekarz miał „w sposób najbardziej pozytywny szukać i wybierać do swego księgozbioru wszystko to, co jest dzisiaj żywe, o co się walczy w dążeniu do przemiany psychiki ludzi, ich sposobu myślenia i rozumowania"166. Wprawdzie Lenin ,Jeszcze w roku 1913 marzył, aby ogromne biblioteki, liczące setki i miliony tomów, udostępnić masom"167, ale przecież nie chodziło mu o tomy romansów czy powieści szpiegowskich.

Próby kontrolowania lektur znajdowały swoje odbicie na łamach czasopism fachowych przez kolejne kilka lat. Jeszcze w 1956 r. w „Poradniku Bibliotekarza” można było przeczytać, iż bibliotekarz ma „wytrącić z jego rąk [czytelnika] książkę bezwartościową, nauczyć go krytycznie i wnikliwie ustosunkowywać się do przeczytanej książki"168 - oczywiście publikowano oficjalne wykazy książek, które należy wycofać z bibliotek. Wciąż pozostawały w mocy apele typu: „My bibliotekarze winniśmy ze szczególną czujnością kontrolować nasze księgozbiory, jesteśmy bowiem narażeni na penetrację wrogiej lub fałszywej ideologii" ${ }^{169}$. Nie ulegało wątpliwości, że bibliotekarz jako świadomy swej roli wychowawca nie powinien propagować książki rozrywkowej, lecz przestawić się na „czytelnictwo uspołeczniające, kształtujące światopogląd

164 Por. E. Iwańczak, III Plenum Komitetu Centralnego Polskie Zjednoczonej Partii Robotniczej a zadania Związku Bibliotekarzy i Archiwistów Polskich, Przegląd Biblioteczny 1950, t. 18, z. 1, s. 98-104.

165 Andrzej T. (Sławno), Listy z terenu, „Poradnik Bibliotekarza” 1951, nr 2, s. 28.

166 J. Filipkowska-Szemplińska Zadania Z. B. i A. P. ..., s. 39.

167 JFS, Wśród książek. Co pisat i mówit Lenin o bibliotekach, „Poradnik Bibliotekarza” 1950, nr 5-6, s. 21-22.

168 A. Narwoysz, Bibliotekarz..., s. 29.

169 E. Iwańczak, III Plenum..., s. 100. Por. też J. Czarnecka, Porządkowanie biblioteki, „Poradnik Bibliotekarza" 1949, nr 2-3, s. 17-19. 
i pogłębiające kulturę"170. Po kilku latach takiej niezłomnej postawy miał szansę ujrzeć efekty - w „Bibliotekarzu” w 1953 r. pisano, że:

Czytelnik znudzony, szukający w książce wrażeń kryminalnych, sensacyjnych czy seksualnych ustępuje dziś miejsca czytelnikowi wyrobionemu, który wie czego chce, który poza powieścią bierze również do ręki książkę naukową, uzupełniając nią swoje wiadomości zawodowe i polityczne ${ }^{171}$.

Stworzenie takiego właśnie czytelnika było głównym celem w tamtym okresie.

Dlatego ścisła kontrola wypożyczeń była konieczna. Sytuacje typu: „«Co Pani zwraca? To ja biorę». I książka wędruje do rąk następnego czytelnika bez względu na to czy jest dla niego odpowiednia, czy naprawdę go zainteresuje i przyniesie mu pożytek" ${ }^{\prime 12}$ nie powinny mieć miejsca w placówkach prowadzonych przez świadomego swej roli bibliotekarza. Brak czasu czy nawał pracy nie mogły usprawiedliwiać takiego postępowania. Najważniejsze w bibliotece są nie czynności techniczne, lecz praca wychowawcza z czytelnikiem. Zaprezentowany powyżej model wypożyczeń miał odejść w przeszłość razem z płatnymi wypożyczalniami książek i „dochodowym, niepedagogicznym nastawieniem do czytelnika". To bibliotekarz, stojący na straży socjalistycznych wartości, miał obowiązek wybrać czytelnikowi odpowiednie pozycje, nie pozwalając na czytanie tych przypadkowych, gdyż „moment doboru książki, poszukiwań i rozważań jest właśnie cennym momentem wychowawczym i nie wolno z niego rezygnować” ${ }^{173}$. Dlatego już w 1949 r. napominano, że „Należy przestrzegać zasady starannego doboru wydawnictw dla poszczególnych czytelników w zależności od ich wieku, przygotowania naukowego i wyrobienia politycznego"174 - jednak warto pamiętać, że tylko bibliotekarz uświadomiony ideologicznie mógł się tym zająć, więc jego profil polityczny nie był bez znaczenia.

Pisano, że książka dociera już wszędzie, ,gotowa spełnić swą funkcję społeczną", jednak nie liczą się tylko wskaźniki ilościowe, trzeba zadać sobie pytanie, czy lektura spełnia swój cel wychowawczy ${ }^{175}$. Nie wolno poprzestać jedynie na wypełnieniu odpowiednich wskaźników, gdyż „Do wątpliwych osiągnięć zaliczyć przyjdzie nawet ilościowe zwiększanie czytelnictwa mało lub bezwartościowych powieści brukowych, kryminalnych itd." ${ }^{176}$. Ludzie

170 J. Korpała, Refleksje..., s. 138.

171 J. Schubert, Miejska Biblioteka Publiczna w Ostrowie Wielkopolskim, „Bibliotekarz” 1953, nr 1, s. 23-24.

172 E. Pawlikowska, Wypożyczanie w bibliotece miejskiej. Uwagi bibliotekarki, „Poradnik Bibliotekarza" 1950, nr 7, s. 9.

173 Tamże, s. 10.

174 Redakcja, Zastosowanie uchwat..., s. 179.

175 S. Gabriel, Urządzenia zwiazane z propaganda ksiażki, „Bibliotekarz” 1951, nr 8-9, s. 114-118.

176 W. Bieńkowski, Ruch wydawniczy i biblioteki wobec zadania aktywizacji kulturalnej społeczeństwa, „Przegląd Biblioteczny” 1956, t. 24, z. 1, s. 53. 
muszą czytać masowo, ale jednocześnie odpowiednie lektury, gdyż „Przy pomocy umiejętnie dobranych książek musimy powoli zmieniać światopogląd i burżuazyjne nawyki, w których wyrósł czytelnik"177. Pojawiały się więc głosy, że potrzebna jest pewna ostrożność, by w walce o liczbę czytelników czy wypożyczonych pozycji nie zejść na manowce, podnosząc statystyki przy pomocy schlebiania gustom „ludzi o drobnomieszczańskich tradycjach i poglądach ćwierćinteligentów". Przed takimi działaniami ostrzegano na przykład w artykule $Z$ doświadczeń wspólzawodnictwa bibliotecznego w pow. białogardz$\mathrm{kim}^{178}$. Nawet współzawodnicząc w liczbie wypożyczeń, nie wolno zniżyć się do udostępniania romansideł Rodziewiczówny, Ireny Zarzyckiej czy Jadwigi Courths-Mahlerowej:

I postanowiliśmy, że nie będziemy dostosowywać naszych bibliotek do żądań takich czytelników, że walczyć będziemy o utrzymanie i zdobycie przede wszystkim takich czytelników, jak ów ob. Japs z Tychowa, robotnik leśny ${ }^{179}$.

Gdyż nie chodzi o zdobycie każdego czytelnika, ale o wychowanie czytelnika nowych czasów - robotnika, chłopa małorolnego czy członka spółdzielni produkcyjnej, który w lekturze szuka ,poznania praw materializmu dialektycznego”, by móc je wykorzystać w „twórczej pracy”. Taka bezkompromisowa postawa miała stanowić wzór dla pracowników bibliotek, świadomych, że

Współzawodnictwo to walka. Walka, w której nie może być bibliotekarzy pragnących uczynić z biblioteki spokojną, beztroską przystań, trzymać się z dala od polityki i społecznych zagadnień, którymi żyje cały naród. Bo i my jesteśmy w pierwszej linii walki o pokój i wykonanie Planu Sześcioletniego ${ }^{180}$.

Zarówno sztuka, jak i kultura w powojennym świecie miały nowe role do odegrania. Nie chodziło o przeżycia estetyczne, ale o kształtowanie nowego człowieka. I dlatego - całkowicie i bezwzględnie - „musi być przezwyciężone hasło „czytelnictwa w ogóle”, tylko dla „przelotnych, emocjonalnych wrażeń" ${ }^{181}$. Propaganda czytelnictwa nie może sprowadzać się do stwierdzenia, że „trzeba czytać”, czy „czytać dużo”. Trzeba zadać pytania - co czytać i jak czytać? W jakim celu czytać? Czytanie ma mieć wymiar praktyczny, utylitarny i dlatego trzeba nim pokierować, trzeba pokazywać czytelnikowi sprawy, którymi żyje tu i teraz, którymi kieruje PZPR. Marceli Poznański pisał: „Dział pracy pedagogicznej bibliotekarza należałoby zgodnie z rzeczywistością nazwać „propagandą aktualnych spraw politycznych, społecznych i gospodarczych

177 Dla każdego coś innego, „Poradnik Bibliotekarza” 1950, nr 2, s. 11.

178 A. Majorek, $Z$ doświadczeń wspótzawodnictwa bibliotecznego w pow. białogardzkim, „Bibliotekarz" 1951, nr 3-4, s. 44-47.

179 Tamże, s. 45.

180 Tamże, s. 47.

181 M. Poz. [Poznański], Z zagadnień bibliotekarstwa i czytelnictwa w prasie, „Bibliotekarz” 1952, $\mathrm{nr}$ 4, s. 120-123. 
poprzez książkę i gazetę"182. Czytelnictwo musi być „organizowane i kierowane". W walce o masowego czytelnika najważniejszy jest dobór książek pod kątem ich zawartości ideologicznej, by zmobilizować społeczeństwo do walki o pokój, o socjalizm, o Plan Sześcioletni.

Mimo różnorakich akcji propagandowych i wysiłków bibliotekarzy upowszechnienie czytelnictwa nie było tak spektakularne, jakby sobie tego życzyły władze. Walki o czytelnika absolutnie nie można było uznać za wygraną. Niektórzy praktycy sygnalizowali, że czytelnictwo zamiast rosnąć - spada. Pomimo wszelkich akcji, konkursów, namów, nieustannej agitacji. Na przykład Walenty Regulski podawał, że w liczbach bezwzględnych czytelnictwo chłopów w 1951 r. było wciąż na poziomie 1949 r., a wśród inteligencji pracującej na wsi nawet się zmniejszyło ${ }^{183}$. W 1954 r. także sygnalizowano, że czytelnictwo wciąż nie stało się zjawiskiem masowym, a tylko takie mogło zadowolić dysydentów. Ale, napominano na łamach „Przeglądu Bibliotecznego”, nie wolno się poddawać, trzeba dotrzeć z książką do każdego chłopa i do każdego robotnika, nauczyć ich korzystania z niej, wychować na stałych konsumentów kultury ${ }^{184}$.

Najtrudniejsze było przekonanie do lektur politycznych, ideologicznych, społecznych. Pojawiały się jednak także optymistyczne doniesienia. W $1953 \mathrm{r}$. J. Schubert z biblioteki w Ostrowie Wielkopolskim informował, iż widać znaczny wzrost wypożyczeń książki naukowej (z 10\% do 30\%), co oznacza, że:

pracownicy bibliotek dobrze zrozumieli swoje zadanie wychowawczego oddziaływania na czytelnika i że czytelnicy dobrze zrozumieli intencje biblioteki przestawiając się na czytanie książek wartościowych dla samokształcenia naukowego i zawodowego oraz wyrobienia społeczno-obywatelskiego ${ }^{185}$.

Radzono także, by na ladzie w wypożyczalni zamiast lekkich pozycji beletrystycznych - najchętniej wypożyczanych przez czytelników bez względu na wiek, zawód czy poziom wykształcenia - wystawiać „lżejszą” literaturę popularnonaukową: życiorysy, biografie, autobiografie, pamiętniki, książki podróżnicze. Przyzwyczajeni do sięgania po pozycje leżące na ladzie, czytelnicy brali je, zwłaszcza że dostawali też drugą pozycję, beletrystyczną. Potem na ladzie wystawiano także literaturę społeczno-polityczną. Można też cierpliwie wycofywać ze zbiorów najbardziej „reakcyjne” lektury i przekonywać do tych lepszych licząc na to, że „Autorzy radzieccy przez artyzm sztuki pisarskiej, przez głębokie wczucie się w dzieje bohaterów i ich zmagań z przeciwnościami

182 Tamże, s. 120-123. Por. też Nowe życie na wsi, „Poradnik Bibliotekarza” 1950, nr 5-6, s. 2-6; B. Tylicka, Czytelnictwo w walce o nowa wieś (Na marginesie konkursu czytelniczego Zwiazku Samopomocy Chłopskiej), „Bibliotekarz” 1952, nr 6, s. 175.

183 W. Regulski, $W$ poszukiwaniu..., s. 37-43.

184 Por. A. Wróblewski, O aktualnych sprawach czytelnictwa i bibliografii (artykut dyskusyjny), „Przegląd Biblioteczny” 1954, t. 22, z. 2, s. 109-119.

185 J. Schubert, Miejska Biblioteka Publiczna..., s. 24. 
szybko ujęli naszych czytelników"186. Bibliotekarka ze Stalowej Woli relacjonowała $\mathrm{z}$ dumą:

Przestali się wreszcie nasi czytelnicy pytać o «Trędowatą», lub «Obcą przy własnym ognisku», a jeśli takie pytanie pada, nasza postawa zlekka [sic!] zgorszona i zdziwiona i podobna reakcja innych czytelników doprowadza do szybkiego wycofania się z niewczesnego żądania ${ }^{187}$; przestają ,zatruwać się” literaturą, znaną z przedwojennych, prywatnych wypożyczalni.

To jednak były raczej wyjątki. Większość tekstów zamieszczanych na łamach czasopism fachowych dotyczyła rozmijania się oczekiwań czytelników i bibliotekarzy. Lektury polecane przez bibliotekarzy niekoniecznie były tymi, o które pytali czytelnicy. Pracownicy bibliotek pisali, że wprawdzie w swoich zbiorach „mają książki mówiące o tym, jak kształtować ustrój socjalistyczny”188, jednak korzysta z nich niewielki procent czytelników - na wsi było to ok. 5,6\% ogółu mieszkańców. Czytelnicy nie chcieli takich lektur, a bibliotekarzy obwiniano, że nie dość się starają, że to przez ich nieudolność tego typu pozycje nie znajdują czytelników. A przecież władzom najbardziej zależało na popularyzacji tej właśnie literatury. To ona miała przynieść robotnikom pomysły racjonalizatorskie, a co za tym idzie, zwiększenie produkcji. To ona miała uświadomić chłopom, że istnieją nowoczesne metody uprawy ziemi i hodowli zwierząt, a spółdzielnie produkcyjne pozwalają na podniesienie wydajności, co w efekcie doprowadzić miało do szybszej budowy socjalizmu ${ }^{189}$. W pracy z czytelnikiem bibliotekarz mógł szukać pomocy właśnie w materiałach zamieszczanych na łamach prasy fachowej, choćby w Informatorze. Jak pracować z ksiązką ${ }^{190}$. Redakcja „Poradnika Bibliotekarza" zapowiedziała także publikowanie 16-stronicowych broszur Dobre ksiązki, omawiających pozycje z bibliotek publicznych pod kątem pracy z czytelnikiem - sylwetka autora, lecz przede wszystkim tło historyczne, społeczne i polityczne książki i krytyczna ocena zagadnień w niej poruszonych.

Mimo metod zapewniających wszechstronną, pogłębioną pracę z czytelnikiem (obok oczywiście wystaw, dyskusji, wieczorów literackich), czyli doboru lektury, informacji bibliograficznej, indywidualnej pracy z racjonalizatorami, z przodownikami rolnictwa, z personelem inżyniersko-technicznym, mimo pomocy samoukom i zaocznym studentom, mimo kół samokształceniowych, konsultacji i wykładów, mimo współpracy z aktywem czytelniczym ${ }^{191}$ maso-

186 M. Łukowska, Prace z czytelnikiem indywidualnym w B-ce Miejskiej w Stalowej Woli, „Bibliotekarz" 1955, nr 4, s. 101.

187 Tamże.

188 A. Majorek, $Z$ doświadczeń..., s. 45.

189 Por. E. Spławińska, Z doświadczeń nad upowszechnianiem czytelnictwa literatury popularno-naukowej, „Bibliotekarz” 1953, nr 2, s. 47-48.

190 Informator. Jak pracować z książka, „Poradnik Bibliotekarza” 1950, nr 3, s. 15.

191 Por. O bibliotekach w Zwiazku Radzieckim, opr. I.R., „Poradnik Bibliotekarza” 1953, nr 4, s. $90-93$. 
wość czytelnictwa - zwłaszcza w wypadku literatury fachowej i politycznejwciąż wydawała się nieosiągalnym celem. Leon Krzemienicki pisał:

upowszechniliśmy beletrystykę, nie książkę”. Dlaczego? „Wydaje się, iż bibliotekarze idą po najmniejszej linii oporu. Wypożyczają książki, których żądają czytelnicy - p o w i e ś ć.

[...] Bibliotekarz, który powinien decydować o poziomie czytelnictwa, ogranicza się do wypożyczania. Książkom zbyt często brak bibliotekarza, który by zalecał je czytelnikowi ${ }^{192}$.

Winą obarczono bibliotekarzy, nie dość zaangażowanych w propagowanie postępowej literatury. Może należało zmienić ich nastawienie do tego typu książek? Problem ten poruszył Józef Podgóreczny ${ }^{193}$, przekonując, że trzeba uwierzyć, że czytelnik poszukuje nie tylko beletrystyki i że nie tylko przy pomocy literatury pięknej można wykonać roczny plan wypożyczeń. Napominał:

Tam właśnie, w gromadach i na przedmieściach, trzeba wykwalifikowanego bibliotekarza, ideologicznie wyrobionego propagatora i agitatora słowa drukowanego, który by umiał zwalczać stare, zakorzenione nawyki, typowe dla owych środowisk ${ }^{194}$.

Skoro nawet bibliotekarz nie zdawał sobie sprawy ze znaczenia książki dla rozwoju kraju, to czegóż żądać od innych grup zawodowych? W Bibliotece Miejskiej w Bydgoszczy próbowano zbadać, na ile kursy ideologiczne wpływają na zwiększenie czytelnictwa. Okazało się, że wpływ mają znikomy. Na kursach dla traktorzystów, dla członków rad narodowych czy pracowników oświatowych, przeznaczonych przecież dla przodowników, którzy mają potem dawać przykład innym, o książce w ogóle nie wspominano ${ }^{195}$.

\section{Zakończenie}

$\mathrm{Z}$ analizowanego materiału wyłania się obraz bibliotekarstwa w dużej mierze poddanego władzy politycznej, dość ochoczo głoszącego nowe idee. Już w 1949 r. ZBiAP deklarował, że zamierza umasowić organizację zrzeszającą bibliotekarzy, zapewnić im przeszkolenie ideologiczne i fachowe (kolejność zapewne nieprzypadkowa), powiązać pracę biblioteczną z zadaniami stojącymi przed Polską Ludową, pogłębić wiedzę pracowników bibliotek o ZSRR itd. ${ }^{196}$. Te właśnie tematy miały wyznaczać horyzonty pracy bibliotecznej.

192 L. Krzemienicki, Z problemów bibliotekarstwa dolnośląskiego, „Bibliotekarz” 1956, nr 3, s. 77 .

193 J. Podgóreczny, Jak popularyzowaliśmy książki polityczno-społeczne i fachowe, „Bibliotekarz" 1954, nr 2, s. 43-45.

194 Tenże, Głos w dyskusji o sprawie czytelnictwa, „Przegląd Biblioteczny” 1954, t. 22, z. 4, S. 318

195 Por. A. Chamera-Nowak, Biblioteki i bibliotekarze partyjni w województwie warszawskim w latach 1949-1954 w świetle dokumentów Komitetu Centralnego PPR oraz Warszawskiego Komitetu Wojewódzkiego PZPR, „Z Badań nad Książką i Księgozbiorami Historycznymi” 2016, t. 10, s. 279-293.

196 Por. J. Kraczkiewicz, Pod znakiem..., s. 141-143. 
Czy wyznaczały? Na ile Związkowi udało się wpłynąć poprzez treści prezentowane na łamach prasy przeznaczonej dla pracowników bibliotek rożnego szczebla na poglądy i postawy bibliotekarzy, to oczywiście bardzo złożona kwestia ${ }^{197}$. Żeby móc kontrolować przekaz i docierać z nim do każdego bibliotekarza Związek wielokrotnie postulował, by każdy pracownik biblioteki stał się jego członkiem ${ }^{198}$. Lecz uzwiązkowienie nie było tak duże, jakby sobie życzył ZG ZBiAP, głównie ze względu na dużą rotację zawodową, związaną z niskimi płacami i brakiem prestiżu. Narzekano ponadto, że czasopisma bibliotekarskie nie docierają do większości pracowników. A nawet jeśli prasa ta dochodzi „do tych szczebli sieci bibliotecznej [gminne czy zakładowe], zbyt mało miejsca poświęca organizowaniu i kierowaniu czytelnictwem, zajmując się sprawami raczej techniczno-organizacyjnymi księgozbioru" "199. Jak widać niektórzy uważali, że jest to prasa wciąż w niewystarczającym stopniu zaangażowana w budowę socjalizmu. Ponadto już kilka lat później na łamach tych samych czasopism przyznawano, że może działania mające na celu wychowanie ideologiczne bibliotekarzy i czytelników nie zawsze przynosiły pożądane efekty:

Mamy już wszyscy wyrobione zdanie o powieści produkcyjnej ze schematycznym pozytywnym bohaterem. Literatura ta wyrządziła czytelnictwu niedźwiedzią przysługę. Niewielu zdobyła, a wielu natomiast odstraszyła swoją sztucznościąą

Albo:

W minionych latach wiele zużyliśmy czasu i wysiłku na omawianie roli książki i bibliotek w budowie socjalizmu, w rozwijaniu naukowego światopoglądu, w podnoszeniu gospodarki narodowej $[\ldots]$ praca ta szła po grudzie i dawała rezultaty dalekie od zamierzonych ${ }^{201}$.

Dogmatyzm i sztywność formułek, tak charakterystyczne dla stalinizmu, często odstręczały zamiast zachęcać do czytania. Podobnie jak narzucanie choćby na łamach „Poradnika Bibliotekarza” - rocznic wartych obchodzenia, świadczące o przecenianiu biurokratycznej, schematycznej i odgórnej strony rozwoju socjalizmu [...] i niedocenianie jego (socjalizmu) społecznej, masowej i twórczej strony rozwoju, zjawisko przeceniania dyrektywy i niedoceniania samodzielności i inicjatywy - wystąpiło we wszystkich przejawach życia ${ }^{202}$, jak w akcie samokrytyki stwierdził członek KC Marian Spychalski. Wtórował mu minister Włodzimierz Sokorski, także krytykując zbytnie

197 Por. na przykład D. Jarosz, Codzienna mobilizacja O propagandzie czytelnictwa ksiązek w Polsce stalinowskiej i trudnościach jej badania, „Z Badań nad Książką i Księgozbiorami Historycznymi” 2011, t. 5, s. 296 i n.

198 Por. choćby już w 1949 r. Z. Hryniewicz, Udziat ZB i AP. ..., s. 123.

199 A. Wróblewski, O aktualnych sprawach..., s. 109.

200 J. Szymanowska, Co, jak i kiedy czyta się w środowisku robotniczym?, „Bibliotekarz” 1956, nr 8, s. 234.

201 C. Kozioł, Na nowej drodze, „Bibliotekarz” 1956, nr 10, s. 281.

202 „Nowe Drogi” 1956 nr 10, s. 107. 
upolitycznienie zagadnień pracy bibliotecznej: „Łopatologia i wulgaryzacja zadań politycznych jest wrogiem czytelnictwa i polityki” ${ }^{203}$. Na łamach „Bibliotekarza” w 1956 r. apelowano już więc: „Nie usiłujmy przy tym propagować książek tylko ze względu na ich temat, nie podsuwajmy czytelnikom zbłąkanych do bibliotek opracowań schematycznych, cukierkowych, bo mogą one tylko zaszkodzić" ${ }^{204} \ldots$

\section{Bibliografia}

\section{Źródła}

Adler J., Z problemów czytelnictwa w domach studenckich, „Bibliotekarz” 1956, nr 11-12, s. 329-335.

Andrzej T. (Sławno), Listy z terenu, „Poradnik Bibliotekarza” 1951, nr 2, s. 27-29.

Apel pierwszomajowy, „Poradnik Bibliotekarza” 1951, nr 4, s. 49.

Bandura L., Z zagranicznych badań nad czytelnictwem dzieci i młodzieży, „Bibliotekarz” 1950, nr 5-6, s. 83-84.

Bieńkowski W., Ruch wydawniczy i biblioteki wobec zadania aktywizacji kulturalnej spoteczeństwa, „Przegląd Biblioteczny” 1956, t. 24, z. 1, s. 47-54.

Bursowa F., Przodownicy czytelnictwa, „Poradnik Bibliotekarza” 1951, nr 1, s. 3-6.

Bursowa F., Z doświadczeń konkursu czytelników wiejskich, „Bibliotekarz” 1954, nr 2, s. 33-35.

Bzdęga S., Współpraca biblioteki szkolnej z dziecięca biblioteka publiczna, „Poradnik Bibliotekarza" 1953, nr 1, s. 4-9.

Chełstowski E., Rola instrukcyjna i organizacyjna kierownika biblioteki powiatowej, „Bibliotekarz" 1949, nr 3-4, s. 62-64.

Cz.K. [Czesław Kozioł], Jednolity front kultury (po Ogólnopolskiej Naradzie Działaczy Kultury i Sztuki), „Bibliotekarz” 1952, nr 5, s. 129-130.

Czarnecka J., Porządkowanie biblioteki, „Poradnik Bibliotekarza” 1949, nr 2-3, s. 17-19.

Ćwiekowa J., Przegląd piśmiennictwa, „Bibliotekarz” 1956, nr 2, s. 47-51.

Daszkowski Z., O wspótpracę bibliotek naukowych z siecia bibliotek powszechnych (po konferencji w Jarocinie), „Przegląd Biblioteczny” 1954, t. 22, z. 2, s. 120-125.

Dawidczyńska M., Co to jest kolejność alfabetyczna, „Poradnik Bibliotekarza” 1953, nr 1, s. 9-12.

Dąbrowska W., Współzawodnictwo w bibliotekach, „Poradnik Bibliotekarza” 1950, nr 3, s. $12-14$.

Deklaracja Zarządu Głównego Związku Bibliotekarzy i Archiwistów Polskich, „Bibliotekarz" 1948, nr 3, s. 34.

Dla każdego coś innego, „Poradnik Bibliotekarza” 1950, nr 2, s. 9-11.

203 Ogólnopolski Zjazd Bibliotekarzy..., s. 89-151.

204 Wimię przyjaźni, „Bibliotekarz” 1956, nr 8, s. 217. 
Draczko S., Nowa forma pracy z czytelnikiem, „Poradnik Bibliotekarza” 1950, nr 5-6, s. 10-12. Dzień walki o pokój i socjalizm, „Poradnik Bibliotekarza” 1951, nr 4, s. 51-60.

Filipkowska-Szemplińska J., O książach szkodliwych, „Poradnik Bibliotekarza” 1950, nr 10-11, s. 13-15.

Filipkowska-Szemplińska J., Zadania Z. B. i A. P. w Polsce Ludowej, „Bibliotekarz” 1949, nr 3-4, s. 38-42.

Filipkowska-Szemplińska J., Zebrania sprawozdawcze bibliotek, „Poradnik Bibliotekarza" 1951, nr 3, s. 38-40.

Fonotow G., O bolszewicka partyjność i zwiazek z praktyka w pracach teoretycznych nad bibliografia, [przeł. T. Remer], „Przegląd Biblioteczny” 1951, t. 19, z. 1-2, s. 1-11.

Gabriel S., Urządzenia związane z propaganda książki, „Bibliotekarz” 1951, nr 8-9, s. $114-118$.

Goryńska K., Planowanie pracy w bibliotece gminnej, „Poradnik Bibliotekarza” 1952, nr 1, s. 2-4.

Grabowska J., Biblioteki przyczyniaja się do podniesienia gospodarki rolnej i hodowlanej (Z doświadczeń biblioteki woj. lubelskiego), „Bibliotekarz” 1955, nr 5, s. 130-132.

Grabowski F., Z książą do robotników, „Bibliotekarz” 1955, nr 11, s. 337-340.

Groniowska B., Zadania dziecięcych bibliotek publicznych, „Bibliotekarz” 1949, nr 11-12, s. $180-181$.

Grycz J., Problemy biblioteczne obecnej doby, „Przegląd Biblioteczny” 1946, t. 14, z. 1, s. 4-24.

Hryniewicz Z., Udział ZB i AP w realizacji ,,polityki bibliotecznej”, „Bibliotekarz” 1949, nr 7-8, s. 123-123.

II Krajowy Zlot Przodowników Czytelnictwa, „Bibliotekarz” 1953, nr 3, s. 65-68.

Informator. Jak pracować z książka, „Poradnik Bibliotekarza” 1950, nr 3, s. 15-16.

Iwańczak E., III Plenum Komitetu Centralnego Polskie Zjednoczonej Partii Robotniczej a zadania Zwiąku Bibliotekarzy i Archiwistów Polskich, „Przegląd Biblioteczny” 1950, t. 18, z. 1, s. $98-104$.

J.K., Biblioteka Publiczna m. Krakowa w roku 1950, „Bibliotekarz” 1951, nr 1-2, s. 30-31. Jagusztyn W., List do bibliotekarzy gminnych, „Poradnik Bibliotekarza” 1953, nr 12, s. 269-272.

JFS, Wśród książek. Co pisat i mówił Lenin o bibliotekach, „Poradnik Bibliotekarza” 1950, nr 5-6, s. 21-22.

Kempka Z., Rola bibliotek w planie 6-letnim, „Bibliotekarz” 1950, nr 3-4, s. 33-40.

Konferencja dyrektorów bibliotek wielkomiejskich, „Bibliotekarz” 1953, nr 2, s. 51-52.

Konferencja w sprawie organizacji bibliotek i czytelnictwa na wsi, „Bibliotekarz” 1952, nr 6, s. 161-163.

Konkurs czytelników wiejskich IV etap 22.VII.1953-22.VII.1954, „Poradnik Bibliotekarza" 1953, nr 9, s. 193-204.

Korpała J., Refleksje przed krajowym Zjazdem Bibliotekarzy, „Przegląd Biblioteczny” 1948 , t. 16 , z. 3-4, s. 125-138. 
Kowalska Z., Notatka o aktywie czytelniczym w Bibliotece SGPiS, „Bibliotekarz” 1953, nr 1, s. 15-17.

Kozioł C., Na nowej drodze, „Bibliotekarz” 1956, nr 10, s. 281-282.

Kozioł C., Współzawodnictwo pracy w bibliotekach, „Poradnik Bibliotekarza” 1951, nr 2, s. 17-19.

Kraczkiewicz J., Pod znakiem wielkich zadań, „Bibliotekarz” 1949, nr 9-10, s. 141-143.

Kraczkiewicz J., Sprawozdanie sekretarza generalnego ZBiAP za czas 7.IV-1.X.1949 r., „Przegląd Biblioteczny” 1950, t. 18, z. 1, s. 60-76.

Krajowa konferencja w sprawie bibliotek dziecięcych, „Bibliotekarz” 1952, nr 3, s. 79-81. Kronika. Udział bibliotekarzy i archiwistów polskich w uczczeniu 70 rocznicy urodzin Józefa Stalina, „Przegląd Biblioteczny” 1949, t. 17, z. 3-4, s. 223-226.

Kronika. Zobowiąania pierwszomajowe, „Przegląd Biblioteczny” 1952, t. 20, z. 2-3, s. 276-281.

Kronika: Protokót Zebrania Delegatów Kót ZBiAP obradującego w dniach 8-9 kwietnia w lokalu Biblioteki Ossolineum we Wroctawiu, „Przegląd Biblioteczny” 1949, t. 17, z. 1-2, s. 128-138.

Krzemienicki L., Z problemów bibliotekarstwa dolnośląskiego, „Bibliotekarz” 1956, nr 3, s. 76-78.

Ksiązki dla dzieci i młodzieży, „Poradnik Bibliotekarza” 1950, nr 10-11, s. 5-9.

Kuciel L., Aktyw czytelniczy pomaga Bibliotece Miejskiej we Wrocławiu, „Bibliotekarz” 1953, nr 1, s. 17-18.

L.B., Czytelnictwo dziecięce zagranica, „Bibliotekarz” 1950, nr 9-10, s. 152.

L.B., Powstanie nowej literatury dziecięcej w Niemieckiej Republice Demokratycznej, „Bibliotekarz” 1951, nr 12, s. 172.

L.B., Walka ze złą literatura, „Bibliotekarz” 1952, nr 1, s. 22.

Łamkow N., Literatura dziecięca w Bułgarii, przełożył K.J., „Bibliotekarz” 1951, nr 7, s. 104-105.

Łączyńska A., O normy pracy dla bibliotekarza (artykuł dyskusyjny), „Bibliotekarz” 1954, nr 1, s. 1-12.

Łukaszewska R., Czytamy o hucie „Czestochowa”, „Poradnik Bibliotekarza” 1953, nr 5, s. 108-113.

Łukaszewska R., Głośne czytanie w bibliotece, „Poradnik Bibliotekarza” 1951, nr 6, s. 84-88.

Łukaszewska R., Jak dobierać książki do czytania w „, Konkursie czytelników wiejskich”, „Poradnik Bibliotekarza” 1953, nr 11, s. 241-251.

Łukowska M., Prace z czytelnikiem indywidualnym w B-ce Miejskiej w Stalowej Woli, „Bibliotekarz” 1955, nr 4, s. 99-103.

M. Poz. [Marceli Poznański], Z zagadnień bibliotekarstwa i czytelnictwa w prasie, „Bibliotekarz" 1952, nr 4, s. 120-123.

Majorek A., Z doświadczeń współzawodnictwa bibliotecznego w pow. białogardzkim, „Bibliotekarz" 1951, nr 3-4, s. 44-47.

Makaruk J., Bibliotekarze i kierownicy punktów bibliotecznych na II Krajowym Zlocie Przodowników Czytelnictwa, „Poradnik Bibliotekarza” 1953, nr 9, s. 204-206. 
Makaruk J., Powiat Nowy Tomyśl w IV etapie konkursu czytelników wiejskich, „Bibliotekarz" 1953, nr 6, s. 178-179.

Manteufflowa M., Aktualne problemy $w$ dziedzinie czytelnictwa, „Przegląd Biblioteczny” 1951, t. 19, z. 3-4, s. 264-276.

Meldunek III Krajowego Zlotu Przodowników Czytelnictwa dla Pierwszego Sekretarza KC PZPR Obywatela Bolestawa Bieruta, „Bibliotekarz” 1954, nr 3, s. 65-66.

Michalska W., Wytyczne dla działów instrukcyjno-metodycznych wojewódzkich bibliotek publicznych, „Bibliotekarz” 1951, nr 8-9, s. 130-132.

Michałowska M., Wspótpraca biblioteki ze szkoła (Z doświadczeń Biblioteki Miejskiej im. L. Waryńskiego w Lodzi), „Bibliotekarz” 1955, nr 2, s. 34-40.

Mikołajski M., O rozwój czytelnictwa w zakładach produkcyjnych, „Bibliotekarz” 1953, nr 5, s. 141-143.

Mikołajski M., Zadania technicznych bibliotek zakładowych, „Bibliotekarz” 1952, nr 2, s. $42-45$.

Młodziė̇ w literaturze polityczno-społecznej, opr. J.B., „Poradnik Bibliotekarza” 1952, nr 2, s. 43-50.

Moje doświadczenia, „Poradnik Bibliotekarza” 1950, nr 4, s. 6-8.

Morsztynkiewiczowa I., O normy czasowe czynności bibliotecznych $w$ bibliotekach naukowych, „Bibliotekarz” 1952, nr 6, s. 179-180.

Na 60-lecie urodzin prezydenta Polski Ludowej Bolestaw Bieruta, „Poradnik Bibliotekarza" 1952, nr 4, s. 65-68.

Na nowej karcie, „Bibliotekarz” 1948, nr 12, s. 177-178.

Narwoysz A., Bibliotekarz - wychowawca i społecznik, „Poradnik Bibliotekarza” 1956, nr 1, s. 27-29.

Nowe życie na wsi, „Poradnik Bibliotekarza” 1950, nr 5-6, s. 2-6.

O bibliotekach w Związu Radzieckim, opr. I.R., „Poradnik Bibliotekarza” 1953, nr 4, s. 90-93.

O przodowników pracy w bibliotekarstwie, „Bibliotekarz” 1949, nr 9-10, s. 171.

Od Redakcji, „Bibliotekarz” 1951, nr 8-9, s. 113.

Od Redakcji, „Poradnik Bibliotekarza” 1950, nr 5-6, s. 8-9.

Ogólnopolski Zjazd Bibliotekarzy [Warszawa 16-18 lutego 1956], „Bibliotekarz” 1956, nr 4-5, s. 89-151.

Pamiętnik Konferencji Krynickiej 3-15 II 1951. Dyskusja, „Przegląd Biblioteczny” 1951, t. 19, z. 3-4, s. 277-282.

Pawlikowska E., Sprawozdawczość w bibliotece, „Poradnik Bibliotekarza” 1951, nr 1, s. 6-8.

Pawlikowska E., Wypożyczanie w bibliotece miejskiej. Uwagi bibliotekarki, „Poradnik Bibliotekarza" 1950, nr 7, s. 9-11.

Pelcowa J., Wstęp, [w:] Bibliografia zawartości „Przeglądu Bibliotecznego” 1927-1976 (r. 1-44), Wrocław 1978, s. 11-15.

Pierwszomajowy apel o wzmożenie wspótzawodnictwa pracy w bibliotekach, „Bibliotekarz" 1951, nr 1-2, s. 16-17. 
Plan czytania, „Poradnik Bibliotekarza” 1951, nr 10, s. 154-157.

Plenum Zarządu Gtównego ZBiAP, „Przegląd Biblioteczny” 1952, t. 20, z. 2-3, s. 290-297.

Po ogólnokrajowej naradzie bibliotekarzy w sprawie czytelnictwa, „Bibliotekarz” 1952, nr 3, s. 67-73.

Podgóreczny J., Jak popularyzowaliśmy książki polityczno-spoleczne i fachowe, „Bibliotekarz" 1954, nr 2, s. 43-45.

Podgóreczny J., Głos w dyskusji o sprawie czytelnictwa, „Przegląd Biblioteczny” 1954, t. 22, z. 4, s. 317-321.

Podgóreczny J., Należy pomóc bibliotekarzom w pracy ideologicznej, „Bibliotekarz” 1953, nr 5, s. 132-133.

Poświęcajmy więcej uwagi wychowaniu młodzieży, „Bibliotekarz” 1955, nr 2, s. 33-34.

Protokół obrad Walnego Zebrania Delegatów ZBiAP, „Przegląd Biblioteczny” 1954, t. 22 , z. 1, s. 87-94.

Przelaskowski R., Uchwała Prezydium Rządu w sprawie rozwoju fachowych bibliotek zakładowych, „Bibliotekarz” 1956, nr 5, s. 163-166.

Przelaskowski R., Znaczenie zagadnień organizacyjnych i planowania w życiu bibliotek, „Bibliotekarz” 1953, nr 1, s. 5-8.

R.F., Zagadnienie usprawnienia i racjonalizacji, „Bibliotekarz” 1949, nr 9-10, s. 152.

Redakcja, Z frontu wspólzawodnictwa pracy, „Bibliotekarz” 1951, nr 5-6, s. 83-85.

Redakcja, Zastosowanie uchwat III Plenum KC PZPR w pracy ZBiAP, „Bibliotekarz” 1949, nr 11-12, s. 178-179.

Regulski W., W poszukiwaniu nowych dróg rozwoju czytelnictwa. Z doświadczeń wojewódzkiej biblioteki publicznej w Szczecinie, „Bibliotekarz” 1953, nr 2, s. 37-43.

Remerowa K., Aktualne zagadnienia w zakresie opracowywania zbiorów bibliotecznych, (wraz z dyskusja), „Przegląd Biblioteczny” 1951, t. 19, z. 3-4, s. 242-264.

Roczne wytyczne do pracy z czytelnikiem, „Poradnik Bibliotekarza” 1952, nr 3, s. 58-63.

Rodziewicz Z., Na nowym etapie wspólzawodnictwa pracy bibliotek, „Poradnik Bibliotekarza" 1952, nr 7, s. 156-160.

Rodziewicz Z., Narada w sprawie czytelnictwa na wsi, „Poradnik Bibliotekarza” 1953, nr 1, s. 1-3.

Rudnicka Z., Akcja letnia łódzkich bibliotek miejskich, „Bibliotekarz” 1955, nr 4, s. 103 105.

Schubert J., Biblioteka pomaga Komisji Poborowej, „Poradnik Bibliotekarza” 1953, nr 1, s. 21-22.

Schubert J., Miejska Biblioteka Publiczna w Ostrowie Wielkopolskim, „Bibliotekarz” 1953, nr 1, s. 23-24.

Skarżyńska J., Jedno z ważnych zadań biblioteki w planie trzyletnim, „Bibliotekarz” 1948, nr 1-2, s. 4-6.

Skarżyńska J., Między nami, „Poradnik Bibliotekarza” 1951, nr 5, s. 70-72.

Skwarnicki M., O stała i planowa politykę nabytków w bibliotekach związków zawodowych, ,Bibliotekarz” 1956, nr 1, s. 2-5. 
Słabek H., O społecznej historii Polski 1945-1989, Warszawa 2009.

Spławińska E., Z doświadczeń nad upowszechnianiem czytelnictwa literatury popularno-naukowej, „Bibliotekarz” 1953, nr 2, s. 47-48.

Sprawozdanie sekretarza generalnego Zarządu Głównego ZBiAP za okres 9.IV.1949-14. IV.1950 r., „Przegląd Biblioteczny” 1950, t. 18, z. 3-4, s. 310-341.

Sprawy ZBiAP. Protokót plenarnego posiedzenia Zarządu Głównego Związku Bibliotekarzy i Archiwistów Polskich odbytego w dniach 28 i 29 stycznia 1950 r. w Państwowym Ośrodku Ksztatcenia Bibliotekarzy w Jarocinie, „Przegląd Biblioteczny” 1950, t. 18, z. 2, s. 170-185.

Stochel S., Plan czytelnictwa w szkole ogólnoksztatcacej (uwagi metodyczno-techniczne), „Poradnik Bibliotekarza” 1952, nr 9, s. 199-204.

Suffczyńska K., Wernerówna M., I-szy Ogólnopolski Kongres w sprawie literatury dla dzieci, „Bibliotekarz” 1947, nr 5-6, s. 99-101.

Szymanowska J., Co, jak i kiedy czyta się w środowisku robotniczym?, „Bibliotekarz” 1956, nr 8, s. 232-236.

Talerman M., Głos w dyskusji nad katalogiem beletrystyki, „Bibliotekarz” 1952, nr 1, s. 21-22.

Talerman M., Nowa forma pracy czytelnikiem, „Poradnik Bibliotekarza” 1952, nr 1, s. 15 16.

Tarnowska M., Mieszkańcy hotelu robotniczego dyskutuja o „ludziach stalinowskich” w oparciu o „Opowieść o prawdziwym człowieku” Borysa Polewoja, „Poradnik Bibliotekarza" 1953, nr 11, s. 260-264.

Telega S., Wielka narada wytwórcza bibliotekarzy Pomorza Zachodniego, „Bibliotekarz” 1950, nr 11-12, s. 178-180.

Trzcińska M., Narada produkcyjna z czytelnikami w Bibliotece Uniwersyteckiej $w$ Łodzi, „Bibliotekarz” 1952, nr 3, s. 85-86.

Tylicka B., Czytelnictwo $w$ walce o nowa wieś (Na marginesie konkursu czytelniczego Zwiąku Samopomocy Chtopskiej), „Bibliotekarz” 1952, nr 6, s. 175-179.

Uczczenie 70-tej rocznicy urodzin Józefa Stalina, „Bibliotekarz” 1949, nr 11-12, s. 202-203.

Udziat bibliotek w zwalczaniu analfabetyzmu, „Bibliotekarz” 1951, nr 1-2, s. 13-14.

Usuwanie ksiązek z biblioteki, „Poradnik Bibliotekarza” 1950, nr 5-6, s. 19-20.

W imię przyjaźni, „Bibliotekarz” 1956, nr 8, s. 217-218.

W rocznice wielkiej Rewolucji Październikowej. List bibliotekarzy woj. szczecińskiego do bibliotekarzy radzieckich, „Bibliotekarz” 1950, nr 9-10, s. 130-131.

W.S., Akcja szerzenia czytelnictwa Biblioteki Publicznej m.st. Warszawy, „Bibliotekarz” 1949, nr 9-10, s. 155-157.

Wasilewski P., Koło Przyjaciót Biblioteki, „Bibliotekarz” 1952, nr 3, s. 81-82.

Wasilewski P., Racjonalizatorstwo - warunkiem wykonania planu 6-letniego, „Bibliotekarz" 1951, nr 3-4, s. 51-53.

Wierzbicka A., Czytelnik czeka - trzeba do niego trafić, „Bibliotekarz” 1955, nr 11, s. 324328. 
Wojciechowski K., Czy dobrze udostępniamy książki $i$ czasopisma rolnicze, „Bibliotekarz" 1954, nr 2, s. 36-40.

Wojciechowski K., Potrzeby czytelnictwa masowego, „Bibliotekarz” 1950, nr 5-6, s. 65-72.

Wojciechowski K., Współczynniki rozwoju czytelnictwa, „Bibliotekarz” 1953, nr 3, s. 71-73.

Wróblewski A., O aktualnych sprawach czytelnictwa i bibliografii (artykut dyskusyjny), „Przegląd Biblioteczny” 1954, t. 22, z. 2, s. 109-119.

Wypowiedź Piotra Jaroszewicza na VIII Plenum KC PZPR, „Nowe Drogi” 1956, t. 10, nr 10, s. 56-58.

Wytyczne w sprawie wspólzawodnictwa pracy w bibliotekach, Bibliotekarz" 1951, nr 3-4, s. 41-44.

Wytyczne organizacji wspótzawodnictwa w bibliotekach powszechnych, „Bibliotekarz” 1952, nr 2, s. 48-51.

Wytyczne przygotowań do Tygodnia Oświaty, Książki i Prasy, „Bibliotekarz” 1951, nr 1-2, s. 14-16.

Wytyczne w sprawie organizacji imprez w bibliotekach w okresie II kwartału 1951 r., „Bibliotekarz" 1951, nr 1-2, s. 10-13.

Wytyczne w sprawie organizacji prasy masowej z czytelnikiem w IV kwartale 1951 roku, „Bibliotekarz” 1951, nr 8-9, s. 128-130.

Z frontu wspólzawodnictwa pracy, „Bibliotekarz” 1950, nr 3-4, s. 42-46.

Z frontu wspólzawodnictwa pracy, „Bibliotekarz” 1950, nr 5-6, s. 74-80.

Z frontu wspólzawodnictwa pracy, „Bibliotekarz” 1950, nr 7-8, s. 118-119.

Z instrukcyjnej działalności biblioteki wojewódzkiej, „Bibliotekarz” 1951, nr 5-6, s. 75-83.

Z życia Stowarzyszenia, „Bibliotekarz” 1955, nr 9, s. 285-286.

Z życia Zwiazku, „Bibliotekarz” 1949, nr 3-4, s. 57-58.

Zżycia Związku. Walny Zjazd Delegatów Kół Z.B. i A.P., „Bibliotekarz” 1950, nr 3-4, s. 59-61.

Z życia Związku. Wyciag z protokółu zebrania Zarządu Głównego Związku w dniach 8 i 9 października 1949 r., „Bibliotekarz” 1949, nr 9-10, s. 162-164.

Zadania bibliotekarzy, „Poradnik Bibliotekarza” 1952, nr 8, s. 169-172.

Zagadnienie norm pracy $w$ bibliotekach ZSRR, opr. J.M., „Bibliotekarz” 1950, nr 7-8, s. 116-118.

Zobowiąania pracowników Biblioteki Narodowej dla uczczenia 8 Rocznicy Wyzwolenia Polski i Manifestu PKWN, „Bibliotekarz” 1952, nr 3, s. 80-81.

Zofia P. z Warszawy, Listy z terenu, „Poradnik Bibliotekarza” 1950, nr 12, s. 14-15.

Zwoliński A., Współzawodnictwo pracy bibliotek w woj. warszawskim, „Bibliotekarz” 1951, nr 8-9, s. 137-138.

Opracowania

Chamera-Nowak A., Biblioteki $i$ bibliotekarze partyjni $w$ województwie warszawskim w latach 1949-1954 w świetle dokumentów Komitetu Centralnego PPR oraz Warszawskiego Komitetu Wojewódzkiego PZPR, „Z Badań nad Książką i Księgozbiorami Historycznymi”" 2016, t. 10, s. 279-293. 
Chamera-Nowak A., Książki, biblioteki i bibliotekarze na wsi polskiej w okresie stalinizmu w świetle dokumentów Centralnego Urzędu Wydawnictw Przemystu Graficznego i Księgarstwa, „Rocznik Bibliologiczno-Prasoznawczy” 2013, t. 5 (16), s. 15-30.

Jarosz D., Codzienna mobilizacja O propagandzie czytelnictwa ksiażek w Polsce stalinowskiej i trudnościach jej badania, „Z Badań nad Książką i Księgozbiorami Historycznymi" 2011, t. 5, s. 295-305.

Jarosz D., Książi pod strzechy. Z badań nad politycznymi uwikłaniami czytelnictwa na wsi polskiej w latach 1949-1956, „Z Badań nad Książką i Księgozbiorami Historycznymi” 2008, t. 2, s. 37-53.

Jarosz D., Polacy a stalinizm 1948-1956, Warszawa 2000.

Łuszpak A., Katalogi rzeczowe w stużbie ideologii (na przykładzie Biblioteki Uniwersyteckiej we Wrocławiu w latach pięćdziesiatych XX wieku), [w:] Nie po myśli władzy. Studia nad cenzura i zakresem wolności stowa na ziemiach polskich od wieku XIX do czasów współczesnych, pod red. D. Degen, M. Żyndy, Toruń 2012, s. 249-262.

Łuszpak A., ,, Nie poszliśmy więc do polityki. Ale oto polityka przyszła do nas” - rola bibliotekarza $w$ okresie stalinowskim ( $w$ świetle materiatów zamieszczanych na łamach polskich czasopism zawodowych), ,Z Badań nad Książką i Księgozbiorami Historycznymi” 2018, t. 12, s. 273-305.

Łuszpak A., Obraz katalogów rzeczowych na łamach polskich czasopism bibliotekarskich w okresie stalinowskim, „Z Badań nad Książką i Księgozbiorami Historycznymi” 2016, t. 10, s. 295-315. 